\author{
Economics Working Paper Series
}

2021/008

\title{
Director appointments, boardroom networks, and firm environmental performance
}

\author{
Mingyuan Chen, Dakshina G. De Silva and Aurelie Slechten
}

The Department of Economics

Lancaster University Management School

Lancaster LA1 4YX

UK

All rights reserved. Short sections of text, not to exceed two paragraphs, may be quoted without explicit permission, provided that full acknowledgement is given. 


\title{
Director appointments, boardroom networks, and firm environmental performance*
}

\author{
Mingyuan Chen ${ }^{\dagger} \quad$ Dakshina G. De Silva ${ }^{\ddagger} \quad$ Aurelie Slechten $^{\S}$
}

\begin{abstract}
Using BoardEx (2000-2017), we create a dynamic network connecting firms and board directors for the United States. We use the Environmental Protection Agency's Toxic Release Inventory to measure environmental performance at the director and firm-level. We examine how a candidate's environmental performance and networks affect director appointments. This allows us to endogenize the effect of directors' environmental experience when studying the impact on firms' chemical releases. We show that firms are likely to appoint influential directors with good environmental records and similar characteristics. Further, boards with good environmental performance and with diverse environmental backgrounds improve firms' environmental performance.
\end{abstract}

Keywords: Network Formation, Firm Organization, Toxic Release, Board of directors

JEL Classification: D85, L21, Q5

\footnotetext{
${ }^{*}$ We like to thank George Deltas, seminar participants at Pennsylvania State University, Monash University, and Maastricht University for their helpful comments. The authors declare that they have no relevant or material financial interests that relate to the research described in this paper.

${ }^{\dagger}$ Department of Economics, Lancaster University Management School, Lancaster LA1 4YX, UK. Email: m.chen18@lancaster.ac.uk

${ }^{\ddagger}$ Department of Economics, Lancaster University Management School, Lancaster LA1 4YX, UK. Email: d.desilva@lancaster.ac.uk

${ }^{\S}$ Department of Economics, Lancaster University Management School, Lancaster LA1 4YX, UK. Email: a.slechten@lancaster.ac.uk
} 


\section{Introduction}

Private firms are increasingly held accountable for their environmental impacts and their efforts to promote sustainable growth. ${ }^{1}$ As a result, investors are becoming conscious of the need for firms to be more ethical and environment-friendly in their business and production operations. For example, the C.E.O. of BlackRock, Larry Fink, said that BlackRock would exit certain investments that "present a high sustainability-related risk" and move more aggressively to vote against management teams that are not making progress on sustainability (Sorkin, 2020). ${ }^{2}$

In this paper, we examine how firms internalize this increasing pressure and the role of directors' network formation in shaping a firm's environmental strategy. Directors are accountable to the firm's shareholders and their main roles include taking the firm's strategic and operational decisions. By serving on the board of multiple firms, directors can agglomerate useful information from various sources, identify new business practices, and advise senior management regarding a firm's environmental strategy. Board directors' networks can, therefore, constitute a key element to improve a firm's environmental performance. This question has two dimensions.

First, we investigate whether a candidate's environmental performance is a factor that firms take into account when they appoint their decision-making board members. A positive answer implies that, besides other performance measures, firms also value environmental performance when determining the suitability of a director for the board. This leads to our next question: how a firm's board of directors influences its environmental performance. To the best of our knowledge, this is the first paper to study whether a firm considers a candidate's past environmental record when hiring a board member. By modelling directors' network formation (through the appointment process), we endogenize the effect of directors' environmental experience when examining their network influence over firms' environmental performance.

To complete our analysis, we compile one of the most comprehensive director-firm level data files ever assembled on environmental performance and board characteristics and networks. We combine data from BoardEx data for North America, the United States (US) Environmental Protection Agency's (EPA) Toxic Release Inventory (TRI) Program,

\footnotetext{
${ }^{1}$ A striking example of this increasing pressure on companies is the judgment from a district court in The Hague (Netherlands) that ordered Royal Dutch Shell to reduce its CO2 emissions by $45 \%$ from 2019 levels, in line with global climate goals (May 2021). This was the first time a court ruled that a large polluting company must comply with the Paris Climate Agreement.

${ }^{2}$ Another example of this trend is the recent removal of two directors from ExxonMobil following pressure from an activist investor, Engine No. 1, regarding ExxonMobil's climate strategy (CNN, 2021).
} 
and the US Census between 2000 and 2017. We build a dynamic firm-director network for North America using information provided by BoardEx, a global data company that compiles public information on board directors and senior management of publicly listed and large private companies.

To obtain measures of firms' and directors' environmental performance, we match BoardEx data with the TRI. The TRI is a national database, established by law, which requires private and government facilities to report annually their pollution prevention activities and how much of certain chemicals they emit into the air or water or send to landfills. The TRI Program currently covers 770 individual chemicals that typically have significant adverse human health and environmental effects. In this study, a firm's environmental performance is measured by its facilities' polluting probabilities and the total sum of pollutants released (measured in toxic pounds). We define a board member's environmental performance by calculating the proportion of their connections to polluting facilities within a firm relative to all connected facilities among firms in the network during the previous period. By using a quantitative measure of pollution, i.e. firms' toxic chemical releases, we take into account directors actual actions or impacts in all the firms he is serving as a board member.

We start our analysis by examining the directors' network formation, using a Bayesian model approach similar to Christakis et al. (2020) and De Silva et al. (2020). Our results indicate that firms tend to appoint directors who share more similarities (captured by pollution-related homophily measures) with existing board members or to the firm itself. Candidates who have greater network influence have a significantly higher chance of being appointed, while candidates with poorer environmental performances are less welcome even if they are influential. This could be due to consideration about the firms' reputation and regulation risk. If an influential director with a 'toxic' environmental record is appointed to a firm, the firm can face criticism from the public and draw the attention of regulators, which can indirectly affect profits. We also find that firms with higher network influence tend to appoint more directors to their boards and directors with long market exposures are more likely to be appointed.

We, then, turn to the second dimension of our problem, i.e., the influence of directors on their firm's environmental performance. As firms very often own more than one facility in the US, we examine facility-level outcomes and exploit the panel structure of our data. We estimate the board's influence on a facility's polluting probability by adopting a probit model and on the total toxic release by using simple linear and censored regression 
techniques. The influence of board members over their firm is measured by the average of all existing board directors' environmental performance. We also control for locationspecific demographic (and geographic) characteristics to control for factors that can affect a facility's location and pollution decisions using US Census data. Our findings suggest that a facility's or firm's environmental performance is significantly affected by its board directors' previous experience. When a boardroom has a higher ratio of directors with poor pollution records, the facilities controlled by this board tend to have more polluting incidents. Further, our analysis shows that a facility controlled by a more diverse board in terms of environmental performance tends to pollute less.

Combining the results from the two analyses, our study shows that the board of directors has a role to play in the move towards more sustainable growth. As firms are under increasing pressure (from consumers or regulatory agencies) to be environmentally responsible, we show that the board of directors and its network is a key determinant in improving a firm's environmental performance through their involvement in a firm's strategic decisions and values definition. Despite the likelihood that firms will appoint directors who are similar to their existing board directors, they also tend to appoint environmentally conscious and influential directors to their boards. This move can improve a firm's overall environmental performance.

There exists an extensive literature on the role of the board of directors. Studies suggest that directors should use their own information, experience, and other resources to proactively help decision-making (Chen et al., 2009; Kroll et al., 2008). Given the strategic nature of environmental sustainability, directors have a clear role to play in this area and a growing literature connects board directors' characteristics and firms' environmental performance. Previous research has focused on directors' legal expertise (De Villiers et al. 2011; McKendall et al. 1999), specific environmental expertise based on their roles or their presence in environmental sub-committees in other boards (Homroy and Slechten 2019), or political and academic experience (Zhuang et al. 2018). Similarly, the existence of a corporate social responsibility (CSR)-focused committee significantly improves a firm's environmental performance (Berrone and Gomez-Mejia, 2009; Dixon-Fowler et al., 2017; García Martín and Herrero, 2020). We add to this literature by considering a measure of directors' environmental performance, based on their actual past actions or impacts. Board diversity is another key factor improving board effectiveness and its importance has been recognized by the European Commission (Commission, 2012). The existing literature shows a positive relationship between a board's gender diversity and its firm's 
environmental performance (Post et al., 2011; Lu and Herremans, 2019). Age/generational diversity improves a firm's information richness, experience, and knowledge in a team, thereby improving its CSR performance (Ferrero-Ferrero et al., 2015). In this paper, we create a measure of board diversity in terms of environmental performance and show that it positively affects the firm's environmental performance.

Our paper also contributes to the literature examining the effects of board connections. Pfeffer and Salancik (2003) argue that directors can facilitate the firms' access to external resources and information. There is evidence of an association between board connections and firm value (Fracassi and Tate 2012; Zona et al. 2018). Studies also indicate that board connections affect M\&A transactions (Cai and Sevilir 2012) or innovation (Chuluun et al. 2017). In the same spirit, board directors' networks can constitute a key element to improve a firm's environmental performance. Ortiz-de Mandojana et al. (2012) find that having a well-connected board tends to increase the probability of adopting proactive environmental strategies. Homroy and Slechten (2019) study the role of shared directorship in firms' pollutant releases in the United Kingdom and find that directors with specific environmental experience leverage their network connections on environmental issues. A key distinction of our paper is the fact that we do not take the director network as given, but empirically model the director appointment process. Additionally, we are not only studying how well connected a director is, but also how 'toxic' their connections are. Finally, the network we use for our analysis consists of all firms, regardless of their size, in North America (and not only publicly listed ones as in Homroy and Slechten 2019 or large firms as in Walls et al. 2012).

Networks are widely used in the Finance literature to represent the interdependencies between organizations in the finance sector (Jackson and Pernoud, 2019, 2020). Lux (2015) provides a dynamic model of interbank credit connections and demonstrates that network formations are random at first but develop preferential relationships due to a learning mechanism. Our paper adds to this literature by considering the role of environmental performance in director network formation.

This paper is organized as follows. In the next section, we describe our conceptual framework. We present the datasets and explain how we combine them to perform our analysis in Section 3. Section 4 lays out the empirical models for both network formation and network influence studies. In the final section, we conclude and discuss the implications of our findings. 


\section{Conceptual framework}

Firms interact with many stakeholders (consumers, employees, shareholders, regulators, etc.) who may be endowed with social, environmental, or ethical preferences. Profitmaximizing firms cannot ignore such preferences as they directly affect the demand for their product, the supply of labor, and/or future social/environmental regulations (CasadesusMasanell et al., 2009; Turban and Greening, 1997; Eichholtz et al., 2010; Maxwell et al., 2000). Achieving a good environmental performance can become part of a firm's profit maximization strategy.

The board of directors is a key component in corporate governance. The board represents the interests of the shareholders and is primarily tasked with monitoring and advising senior management. ${ }^{3}$ With respect to the advisory role, board directors create firm value by using their own information, experience, and other resources to proactively help strategic and operational decision making and determining the values to be promoted throughout the company (Kroll et al., 2008). Resource and information provision is crucial in the context of environmental sustainability as improving environmental performance may require the adoption of new business practices or large investments new environmentally efficient technologie with uncertain long-term returns.

As pointed out by resource dependence theory (Pfeffer and Salancik, 2003), board directors' networking with the external environment is a key element in their ability to increase firm value. Directors' social capital emerges from their relations with other firms' directors and outside individuals (Walls et al., 2012) and provides channels of communication and information that help in acquiring outside resources (Hillman and Dalziel, 2003). By sharing directorship in different companies, directors are exposed to various environmental strategies or investment opportunities and can exchange ideas and information related to good environmental practices. This might give them a comparative advantage in their advisory role.

To examine the role of directors' network formation in shaping a firm's environmental strategy, we consider a network where directors and firms are nodes. A link between a director and a firm implies that this director is serving on the board of the firm. Figure 1 provides an example of a network where we focus on two directors (red nodes). The

\footnotetext{
${ }^{3}$ Under state corporate law, shareholders generally have the right to elect directors at the annual shareholder meeting (sections 211 and 216 of the Delaware General Corporation Law, for example). The board generally nominates director candidates. Companies also adopt bye-laws authorizing the board to elect directors to fill board vacancies and newly created directorships. However, this eliminates a key shareholder power to ensure that directors act in their best interests.
} 
brown and green nodes represent firms, while the blue nodes represent the other directors serving on the boards of those firms. Firms are characterized by their environmental performance. In the example, the green (respectively brown) nodes represent firms with good (respectively poor) environmental performance. In our setting, a director's environmental performance will be a function of the past environmental performance of the firms they are connected to. In Figure 1, both directors have two 'pollution links' as they are connected to two firms with poor environmental performance. However, one director is serving on the board of three firms, while the other director is connected to seven firms. The director with seven connections will, therefore, be considered as having a better environmental performance.

In our analysis, we first investigate the directors' network formation. The appointment of a board member represents the formation of a link between a director and a firm. In each period $t$, a firm will determine the suitability of a director for the board. A firm can appoint more than one director to its board and hiring decisions are independent of each other. Applicants are eligible to apply for and hold multiple positions simultaneously. If achieving good environmental performance is part of the firm's objective, we can make the following testable hypothesis:

Testable hypothesis 1: Appointing a new candidate director or continuing with an existing candidate in period t depends on the candidate's past environmental performance (in period $t-1)$.

Westphal and Zajac (2013) note that existing directors tend to favor colleagues who have more similarities (homophily) on major demographic characteristics. The same reasoning can be applied to environmental performance:

Testable hypothesis 2: Firms tend to appoint directors sharing more similarities in terms of their environmental performance with existing board members.

In addition, board directors with more social capital are able to gain greater influence within their boards. They will also have more opportunities to leverage their network to provide information and resources to advise senior management.

Testable hypothesis 3: We expect that firms will be willing to hire directors who are better connected.

Once directors are appointed, they will shape the firm's environmental strategy based on their own past environmental experience and the information they can leverage from 
their networks. This leads to our next question: How does a firm's board of directors influence its environmental performance. Directors make collective decisions for their firms. These decisions will affect all its facilities' environmental performance.

Testable hypothesis 4: A facility environmental performance will reflect the average environmental performance of the directors on its board.

The literature following the seminal paper by Lazear (1998) also suggests that diversity in skills and education may generate knowledge spillover among the employees within a firm, which positively affects firm performance. The same argument could apply to board diversity in terms of environmental performance. Differences in environmental performance reflect different experience or exposure to different environmental issues, which might generate some information spillovers within the board.

Testable hypothesis 5: Board diversity (in terms of environmental performance) will improve a facility environmental performance.

\section{Data}

The data used in this analysis combine three main sources for the period between 2000 and 2017. Facility-level pollution data are taken from the Toxic Release Inventory (TRI) Program. The director-firm-level data for all reporting US (United States) companies are gathered from BoardEx. Census tract-level data are collected from the US Census Bureau.

Note that, while TRI and Census data are publicly available, BoardEx data are not publicly available. We are able to access BoardEx data under the terms of a non-disclosure agreement and interested researchers can access or purchase these data from BoardEx. ${ }^{4}$

\subsection{TRI data}

TRI data provide information regarding a facility's environmental performance. The TRI Program, administrated by the EPA, is a resource for learning about toxic chemical releases and pollution prevention activities reported by private and federal facilities. The origins of the TRI Program date back to the Union Carbide chemical plant disaster in Bhopal, India on December 4, 1984 and a similar serious chemical release at another Union Carbide plant in West Virginia in 1985. As a response to these disasters, the US Congress passed the Emergency Planning and Community Right-to-Know Act (EPCRA) in 1986. ${ }^{5}$ The goal

\footnotetext{
${ }^{4}$ https://corp.BoardEx.com/client-segments/academics-and-non-profit

${ }^{5}$ see, https://www.epa.gov/epcra
} 
of the EPCRA was to support and promote emergency planning and to provide the public with information about pollution prevention activities and releases of toxic chemicals in their community. Section 313 of the EPCRA established the TRI. One of the objectives of TRI data is to support informed decision-making by communities, government agencies, companies, and others.

To be included in the TRI Program, a facility needs to meet three criteria. First, the facility should belong to an industry sector that is covered by the TRI Program. Second, it should employ 10 or more full-time equivalent employees. Third, the plant should manufacture, process, or otherwise use a TRI-listed chemical in the quantities above the threshold levels each year. Note that the facility must prepare and submit a TRI reporting form for each chemical for which the reporting requirement is triggered. The TRI Program currently covers 770 individual chemicals that typically have significant adverse human health and environmental effects.

In our analysis, we include all mandatory TRI reporting plants in the US. Note that TRI reporters are not necessarily polluters, i.e. they are not necessarily reporting toxic chemical releases. The TRI Program specifies that a facility has to report a release when this facility exceeds the minimum chemical release reporting requirements. This requirement is expressed in toxicity levels. Hence, a facility reports all chemical releases by total toxicity levels and not by the amount of chemical released. Further, TRI data provide information about a facility's geo-coded address, parent firm (if applicable), and the industry sector.

In Tables A.1 and A.2, we report the summary statics for TRI data. In Table A.1, we observe 42, 212 unique facilities from 19,915 firms in 30 industry sectors from 2000 to 2017. In our analysis, we use the sum of all pollutants' toxicity per facility given by the EPA. The average amount of toxicity released by a facility is 124,680 pounds. Further, approximately $80 \%$ of the facilities released pollutants at least once over our sample period. The yearly breakdown of the unique number of facilities, firms, and average toxicity release is shown in Table A.2. On average, there are about 35, 000 facilities per year (Table A.2).

\subsubsection{Facility- and firm-level environmental performance}

To conduct our analysis, we construct measures of environmental performance at facilityand firm-level using TRI data. One advantage of using TRI data is that they constitute a quantitative and comparable measure of environmental performance as opposed to scorebased measures like ESG (Environmental, Social, and Corporate Governance) standards. 
Additionally, these score-based measures are typically available for listed firms only, while TRI reports are filled by all facilities meeting reporting requirements. This implies that we can study and compare the environmental performance of listed and non-listed firms and firms with or without a board. It is also important to mention that the information about firms' toxic releases and waste management practices are made publicly available by the EPA and is subject to comprehensive coverage in the media and by the regulators. Studies show that investors are paying attention to the information from the TRI. There is evidence that companies incurred negative stock returns following the disclosure of the TRI and following media coverage of their toxic releases (Hamilton, 1995; Khanna et al., 1998).

We create measures of environmental performance at the facility- and firm-level. The first facility-level measure is a dummy variable, pollute, which takes the value 1 in a given year if the facility reports a release of toxic chemicals above the reporting threshold to the TRI, and zero otherwise. Our measure of environmental performance at the firm-level, polluting ratio, is defined as the proportion of facilities whose releases are above the TRI reporting threshold relative to all its facilities in a given year. Secondly, we use the facility's total toxic releases in a given year. Further, summing up all facilities' toxic releases by industry, we construct an industry-level total release per year (for the industries identified in the TRI data). This will allow us to control for industrial heterogeneity in our analysis.

In Table A.1, we can see that the average probability that a facility pollutes (i.e. reports a toxic release) is about $53 \%$. At the firm-level, the average proportion of facilities reporting a release within a firm is about $43 \%$. In Table A.3, we present summary statistics by industry sector. The metal mining industry is the most polluting sector while the publishing industry is the cleanest sector among the industry sectors based on average toxicity releases per facility.

\subsection{BoardEx}

To create a director-firm-level network, we use information provided by BoardEx, a global data management firm that specializes in relationship mapping and intelligence. BoardEx data contain more than 2 million profiles of public, private, and not-for-profit organizations and more than 1.5 million people around the globe. Director and firm profiles available in BoardEx include high-level details about the company board structure along with current, upcoming, and historic executives. Other details include important adviser information and a list of other key senior management. These in-depth profiles show the relationships 
between and among individuals as well as firms. Each person in the database is individually researched by BoardEx because they are connected at a senior level with a major company. Further, BoardEx firm-level data contain the information on firms' directors, directors' start dates and end dates, firm types, and industry sectors. BoardEx updates the data within 24 hours of the point of disclosure. ${ }^{6}$

In our study, we use the BoardEx dataset for North America. The North America BoardEx data provide the US director network but also capture part of the international director network as well. This is due to the fact that some multinational firms conduct business activities in North America. Note that we focus only on directors who are decision-making board members because our objective is to evaluate how the board of directors can influence a firm's environmental strategy.

In Tables A.4 and A.5, we provide summary statistics for the firms reported in the North American BoardEx data. Between 2000 and 2017, we observe 119,607 unique directors in 157,997 firms. On average, a firm has about 2.5 directors. On average, directors' market exposure is about 10.6 years while their term in a firm is about 5.6 years. Their probability of being associated with a polluting firm (i.e., a firm that has at least one facility reporting a toxic release to the TRI Program) is about $4.9 \%$. With these data, we create a firm-director network for the whole US that we will use in the empirical analysis.

In Table A.5, we report the unique number of firms and directors by year. Despite the increase in the number of firms, the average number of directors per firm decreases over the years. This suggests that these directors are serving on more boards and that firms are likely to become better connected.

\subsection{The US Census Tracts}

Next, we collect US census tract information published by the United States Census Bureau to control for plant locations' demographic characteristics. Census tracts are relatively small and permanent statistical subdivisions of a county during census years. The minimum population of a tract is 1,200 and the maximum is 8,000. Given that our data span two census periods, we consider 2010 locations as fixed geographic locations. From the census data, we gather information regarding tract-level population density, minority ratio (i.e. proportion of non-wite population), proportion of individuals with higher education (college degree), and median household income for all available years. Our dataset

\footnotetext{
${ }^{6}$ see, https://www.boardex.com/. Further, note that BoardEx is a subscription-based service.
} 
includes all tracts in the US (73, 082 tracts), including tracts with military installations that do not report demographic information. We denote these tracts as special tracts.

Note that, prior to 2007, census data did not report estimates by year. As in De Silva et al. (2016) and De Silva et al. (2021), we linearly impute and estimate the missing data to estimate the population density, minority ratio, proportion of individuals with a college degree, and median household income from 2000 to $2008 .^{7}$

We report these summary statistics for all tracts in Table A.6. On average, a tract has a population of 4,133 and a population density of 5,165 per square mile. Each tract has about 1,040 households and the median household income is about $\$ 64,000$. For a given tract, on average, the minority ratio is about $24 \%$ while the college-educated ratio is about $26 \%$. Additionally, we identify tracts that are located along the Canadian and Mexican borders and tracts that are located in a Metropolitan Statistical Area (MSA), urban counties, rural counties, and coastal counties.

\subsection{Matching TRI, BoardEx, and Census data}

To conduct our analysis, we match the TRI and BoardEx datasets. This matching is not a trivial task because the two datasets are created separately and firms can be recorded under different names. We start by directly matching the TRI facilities (for which we have the name of the parent company) with the BoardEx firms by firm name. This method can only match parts of the two datasets. We, therefore, take advantage of the additional information provided by BoardEX to increase the accuracy and the proportion of matched facilities (previous company names, firms' addresses, contact details, websites, board structure).

This approach allows us to tackle three major challenges. First, firms can change name. For example, 3M Co. was Minnesota Mining \& Manufacturing co. prior to 2002. BoardEx also has public listing information including IPO dates and/or delisting dates. Advanced Disposal Services Inc. was listed in 2016 and its name was changed from Ads Waste Holdings Inc prior to its public listing. Second, using the merging and acquisition information provided by BoardEx, we were able to match TRI facilities to their correct firm in BoardEx. This is particularly useful as some TRI facilities fail to update their parent companies due to changes in ownership. For example, Forest River Inc. was acquired by Berkshire Hathaway in 2005 and some of its facilities were still reporting their

\footnotetext{
${ }^{7}$ Before imputation, the average population size is 4,275 , the average white population is 3,257 , the average population with a college degree is 664 , and the average median household income is $\$ 67,834.22$.
} 
parent company as Forest River Inc. after 2005 instead of Berkshire Hathaway. Finally, the information available in BoardEx enables us to match subsidiaries with their parent firms. For example, Volkswagen AG and Volkswagen Group of America are recorded in the TRI dataset as two different parent companies, but Volkswagen Group of America is controlled by Volkswagen AG. Therefore, in our analysis, we consider the facilities from Volkswagen Group of America as being part of Volkswagen AG.

It might be the case that, for a given year, a firm appears in one dataset but not in the other. ${ }^{8}$ The next step consists in filling in the missing years based on a firm's (or director's) first and last appearance in both datasets. This step is based on the rationale that, if a firm exists in one dataset for a given year, this firm should also exist in the other for that same year. Once the TRI facilities are matched with their parent firms' board information gathered from the BoardEx data, we use the facilities' geo codes to find their location in a tract and obtain their local demographic information. Using this method, we are able to match 2,895 TRI-reporting firms with at least one board director recorded in BoardEx from 2000 to 2017. These firms are responsible for the daily operations of 19,099 different TRI-reporting facilities.

In Table 1 we provide summary statistics for observations used in the facility-level environmental performance analysis. In this analysis, we use environmental performance data between 2001 and 2017 and all explanatory variables are lagged, which implies that we lose all facilities that are observed only once during the sample period. Hence, in our analysis sample, we have 2,873 TRI-reporting firms with at least one board director. These firms account for about $46 \%$ of all TRI-reporting facilities and each firm has about 6.5 facilities. We also observe 16,162 firms without a board member that have 22,063 facilities. These non-board member firms have about 1.4 facilities per firm. This indicates that firms with board members are large firms with five times more facilities per firm compared to non-board member TRI-reporting firms. Note that these TRI-reporting firms are located in 18,183 tracts out of the 73,082 tracts defined by 2010 US Census data.

\footnotetext{
${ }^{8}$ For example, private firms in the BoardEx data do not have to continuously report board information as private firms do not require to disclose their board structures. Missing data are also common in BoardEx data in early years where they report only the board members' start and end years. Submitting a TRI report is a federal requirement for firms meeting the reporting criteria. However, it might be the case that for some period of time a firm does not meet all these requirements and does not need to report (for example, if it has less than 10 full-time employees).
} 


\subsection{Director network and environmental performance}

Using the information from BoardEx (see Tables A 4 and A.5 for summary statistics), we build a network in which directors and firms are nodes and the appointment of a board member represents the formation of a link between this director and the firm. Figures 1 and 2 present a sub-network of the two most influential directors (determined by their eigenvector centrality measures) among all directors who are connected to at least one firm in the TRI dataset (green and brown nodes) in 2017. The blue nodes represent the other directors in the network. Firms in the network are characterized by their environmental performance based on the information from the TRI dataset. Brown nodes represent firms that have at least one toxic release, while green nodes represent firms without any toxic releases. Figure 1 only shows nodes which are no further than two edges from the most influential directors (red nodes). When allowing more distanced nodes in the graph, the size increases exponentially. Figure 2 includes all nodes that are within a distance of four from any of the two most influential directors. The number of nodes increases by 1,316, and the number of edges increases by 1,815 compared to Figure 1.

\subsubsection{Director-level environmental performance}

To capture a director's environmental performance, we use two different measures that depend on the past environmental performance of all the firms a director is connected to, whether they are reporting toxic releases to the TRI or not. First, the director-level polluting ratio is constructed as the ratio of the total number of polluting facilities relative to the total number of plants of which they are a board member in the previous year. Next, we use degree centrality (i.e., the number of direct links) to create a measure of directors' environmental performance. Note that, as mentioned earlier, we use the full network (based on BoardEx data) to compute the centrality measures and not only the network of directors and firms matched with the TRI data. Instead of using the degree centrality measure directly, we calculate the proportion of 'pollution links' relative to their total links, denoted as relative pollution degree centrality. We define 'pollution links' as the number of connections that a director has to firms that had at least one toxic releasing facility in the previous year. This measure provides a director's overall environmental performance and captures a director's involvement in the polluting firms relative to their involvement in all companies. In Figure 1, the top two directors have degree centrality measures of seven and three. Both directors have two 'pollution links' as they are connected to two firms 
with at least one toxic releasing facility in the previous year. However, the director with a degree centrality of seven will be considered as having a better environmental performance as relative pollution degree centrality is two out of seven, compared to two out of three for the other director.

\subsubsection{Network influence}

To capture director- and firm-level network influence, we use eigenvector centrality. Eigenvector is a centrality measure that captures a node's influence based on the pattern of the entire network. A value of one for the eigenvector centrality measure represents the most influential director (or firm) in the entire network at a given time. Those directors and firms with scores of zero are isolated nodes-not connected to any other firm or director. A director's eigenvector centrality is based on the centrality of their first-degree connections. In other words, a director will be influential (i.e., have a high score for the eigenvector centrality) if they are connected to well-connected directors.

\subsubsection{Director-firm level homophily measures}

To test our prediction that firms will appoint directors sharing more similarities with existing board members, we identify three homophily measures: 1) the difference in a director's relative pollution degree centrality with respect to board members' average relative pollution degree centrality, 2) the difference in a director's pollution ratio with respect to the firm's pollution ratio, and 3) the difference in a director's influence and the firm's influence.

\subsubsection{Board Diversity}

The last prediction in our conceptual framework, was that once appointed, board diversity in terms of environmental record might positively affect a firm's environmental performance. Based on the director-level relative pollution degree centrality, we create a measure to capture a board's diversity in terms of environmental performance. The board range is defined as the difference between the maximum and the minimum of the directors' relative pollution degree centrality. 


\section{Empirical analysis}

Our empirical analysis is divided into two parts. We first examine how firms appoint their board directors. In particular, we investigate whether firms value directors' past environmental performance when determining their suitability for the board. Second, we show, once appointed, how these board directors influence firms' environmental performance.

\subsection{Director appointments}

In the first part of our analysis, we study directors' network formation through the board appointment process. The appointment of a board member represents the formation of a link between a board member $(d)$ and a firm $(j)$. Hence, our dependent variable is equal to 1 if a firm, in time period (year) $t$, forms a link with a director and 0 otherwise. To study whether directors' environmental performance is a key determinant of a firm's board appointment decisions, we model the probability, $\operatorname{Pr}\left(l_{d, j, t} \mid R_{d, t-1}, N_{d, j, t-1}, g\left(N_{t-1}\right), D_{d, t-1} ; \theta_{t}\right)$, of a link $l_{d, j, t}$ established by firm $j$ to director $d$ at time $t$ as a function of an unknown vector of parameters denoted by $\theta_{t}$. A director's past environmental performance is denoted by $R$. We use the observed data of the structure of the network $N$ (e.g. director's and firm's influence). We also control for the homophily measures between potential directors and firms $\left(g\left(N_{d, j, t-1}\right)\right)$. We consider director market exposure $D$, which is a proxy for director experience and is computed as the number of years since a director's first appearance in the BoardEx data at a given time. We postulate a prior distribution for $\theta$. Then, we derive the posterior distribution for $\theta_{t}$ and calculate the probability of link formation for different values of $R_{d, t-1}, N_{d, j, t-1}, g\left(N_{d, j, t-1}\right)$, and $D_{d, t-1}$.

The probability of forming a link between firm $j$ and director $d$ at time $t$ is modeled as:

$$
\begin{aligned}
& \ln \left(\frac{\operatorname{Pr}\left(l_{d, j, t} \mid R_{d, t-1}, N_{d, j, t-1}, g\left(N_{d, j, t-1}\right), D_{d, t-1} ; \theta_{t}\right)}{1-\operatorname{Pr}\left(l_{d, j, t} \mid R_{d, t-1}, N_{d, j, t-1}, g\left(N_{d, j, t-1}\right), D_{d, t-1} ; \theta_{t}\right)}\right) \\
= & \gamma+\rho R_{d, t-1}+N_{t-1}^{\prime} \beta+\left(g\left(N_{d, t-1}-N_{j, t-1}\right)^{\prime} \Psi\left(g\left(N_{d, t-1}-N_{j, t-1}\right)\right)\right)+\delta D_{d, t-1}+\tau_{t}+\epsilon_{d, j, t}
\end{aligned}
$$

where the term $\left(g\left(N_{d, t-1}-N_{j, t-1}\right)^{\prime} \Psi\left(g\left(N_{d, t-1}-N_{j, t-1}\right)\right)\right)$ is the disutility (cost) of having a difference in homophily between potential director candidates which relates to firm $j$ in period $t-1$ (see Christakis et al. (2020) for a similar measure of homophily). $\Psi$ is a diagonal matrix. The function $g$ is a measure of homophily that is expressed as the 
absolute value of the difference in environmental performance between director candidates and/or firms. We assume that the $\epsilon_{d, j, t}$ are independent across all $j$ and $d$ at a given time, $t$, and that they follow a logistic distribution.

If the links are independent of each other, then this would be a standard logistic regression. However, the purpose of exploring a network structure is to account for interdependencies among directors and firms. Therefore, in the link formation analysis, following Jackson (2010) and Christakis et al. (2020), we exploit the latest developments in Markov-Chain-Monte-Carlo (MCMC) methods to generate different network-related posterior distributions for any given specification of parameter based on prior information on link-formation choices. Specifically, we use a Bayesian MCMC technique based on a hybrid Metropolis-Hastings algorithm with Gibbs sampling updates to estimate our posterior mean and posterior standard deviations. In this way, one can search over the set of parameter estimates to find one that leads to the highest likelihood of getting a network distribution that looks similar to the observed network-related distribution. ${ }^{9}$

Further, the Bayesian approach offers several advantages. First, it continuously updates posterior estimates given prior information on link formation and network characteristics. Second, the MCMC gives us the finite-sample properties of the resulting estimates rather than asymptotic approximations. Additionally, incorporating a non-parametric assumption on the posterior distribution makes the specification of the model more flexible and, hence, the results are more robust (Li and Zheng, 2009).

Based on the predictions of our conceptual framework, we expect that directors with cleaner environmental records and influential directors are highly sought out by firms. Also, directors with similar environmental performances are more likely to connect with each other. Further, more experienced directors are expected to be more likely to form a link.

\subsubsection{Pool of candidates for the director network formation}

In any given period, the firm makes a decision to appoint new directors or renew directors from its preferred pool of 'applicants' (directors). Applicants are eligible to apply for and hold multiple positions simultaneously. A firm can appoint more than one director to its board and hiring decisions are independent of each other. Firms make final decisions on their candidates and hire them simultaneously for a given year.

Potential candidates have to be in the reach of this firm, which is determined by their

\footnotetext{
${ }^{9}$ Gelman (2004) provides a detailed description of the Bayesian method used in this paper.
} 
positioning in the network. Moreover, as in any job opening, firms will make an initial selection of potential candidates based on homophily measures. To identify these potential pools of candidates, we take the following steps. First, for each firm, we construct the maximum difference in the relative pollution degree centrality (with respect to other board members' average relative pollution degree centrality) a director has had from 2000 to 2017 with its board. Similarly, we measure the maximum difference between all the appointed directors' polluting ratio and the firm's polluting ratio during the sample period. Then, we consider all candidates that fall within either of these two maximum values as a potential candidate for a given board. Based on these cut-offs, we identify a possible 8,487,170 director-firm pairs for all TRI-reporting firms with directors for all years. On average, this corresponds to about 300 potential candidates per firm in a given year. We use this sample in our network formation analysis.

One potential concern with our measures of environmental performance and homophily is that they could capture industry expertise. For example, directors currently serving on the board of chemical companies will have a greater exposure to polluting facilities and poorer environmental performance than directors in less polluting sectors. Other firms in the chemical industry might want to hire those directors for their expertise, rather than their similarities in terms of environmental performance. To address this issue, for all the directors matched with at least one TRI firm, we compute the number of TRI-reporting firms and the number of non-TRI-reporting firms a director serves as a board member. On average a director is connected to 3 TRI-reporting firms and 3 non-TRI-reporting firms. Moreover, looking more closely at the TRI sectors (3-digit NAICS code) only, a director is on average connected to TRI-reporting firms from 4 different sectors. Note that a firm can be in more than one sector.

\subsubsection{Network formation analysis}

For empirical link-formation analysis, as mentioned, we used a Bayesian hybrid MetropolisHastings algorithm with Gibbs sampling updates to obtain posterior values for each network parameter based on prior information on link-formation choices. This is similar to Christakis et al. (2020) and De Silva et al. (2020). Further, we take advantage of the full dataset instead of taking random draws from the samples. ${ }^{10}$

Our analysis of link formation focuses on one side of the market (the director market).

\footnotetext{
${ }^{10}$ Note that this is computationally demanding. We use Lancaster University's High Performance Computer to estimate these Bayesian models.
} 
Firms decide to appoint directors to their boardrooms. As a result, directors are considered passive actors in our setting, exerting no decision power with respect to the link formation. We use uniform priors for the regression coefficients and an inverse-gamma prior with shape and scale parameters of 0.1 and 0.1 for the error variance. In all our Bayesian estimates, we use 10,000 iterations and omit the first 2,500 to mitigate possible start-up effects. However, one must verify the convergence of MCMC before making any inferential conclusions about the obtained results. In our exercise, we observe that the posterior distribution looks normal. Further, the kernel density estimates based on the first and second halves of the sample are very similar to each other and are close to the overall density estimate.

Table 2 shows the summary statistics of the variables used in the Bayesian estimation. Column 1 presents summary statistics for all 2,873 firms with directors, while Column 2 provides information for 661 listed firms with directors. Listed companies with shares traded on an official stock exchange might be more responsive to the increasing pressure to become environmentally responsible. The data are for all potential directors matched with a given firm in a given year. On average, the unconditional probability of a director and a firm forming a direct link is $1.9 \%$. On average, a director's past pollution ratio is 0.446 . Considering homophily measures, the absolute difference in a director's relative pollution degree centrality with respect to other board members' average relative pollution degree centrality is 0.324. Similar inferences could be made for other homophily measures as well. Further, a director's average exposure in BoardEx is about 5.5 years.

Table 3 presents the means and credible intervals of the posterior distributions of our model parameters for all the firms in our sample (Column 1) and for listed firms only (Column 2). ${ }^{11}$ In Columns 1 and 2, the mean of the posterior distribution is about 0.1 and the $95 \%$ credible interval for the director's influence lies strictly in a positive range of values. This result indicates that firms tend to connect with influential directors. However, on average, if an influential director has a poor environmental performance, firms would tend to refrain from connecting with him or her. This observation is consistent with our testable hypotheses 1 and 3 and can be derived from the fact that, in both specifications, the mean of the posterior distribution of a director's past pollution ratio interacted with the director's influence is strictly negative. Finally, influential firms tend

\footnotetext{
${ }^{11}$ Note that we do not include a listed dummy (and its interactions with all other variables) in our director-firm level estimations because this dummy variable would be highly correlated with a firm's eigenvector centrality. Listed firms are usually large and, as a result, have larger boards (with more connections) and higher eigenvector centrality.
} 
to connect with more directors as they tend to have more board members. The mean of the posterior distribution for a director's past pollution ratio is negative, but it lies strictly in the negative range only for the listed companies. This is in line with previous research analyzing investor reactions to public disclosure of TRI. Khanna et al. (1998) show that listed firms in the chemical industry incurred statistically significant negative stock market returns following the publication of TRI data, and that these losses had a significant impact on their subsequent toxic releases. It illustrates that listed companies might be more responsive to the increasing pressure to become environmentally responsible by hiring directors with a good environmental record.

Considering homophily measures, our results are in line with our second testable hypothesis and indicate that an increase in the differences in a director's relative pollution degree centrality with respect to that of other existing board members decreases the probability of their being appointed as a board member. This probability is also lower when the differences in a director's pollution ratio and influence with respect to the firm increase. As expected, exposure in the market increases the probability of being appointed as a director. ${ }^{12}$

\subsection{Network influence on environmental performances}

Having discussed the determinants of network formation, we empirically investigate how the features of a network and a firm's boardroom characteristics affect pollution probabilities and toxic releases. The posterior estimates for all firms in our sample from Table 3 (Column 1) will be used to calculate director-firm-level network formation probabilities. This will allow us to address endogeneity concerns related to the use of the actual number of direct director-firm links in the firm-level environmental performance analysis.

\subsubsection{Facility-level probability of pollution}

Our dependent variable, pollute $_{f, i, j, l, t}$, takes the value 1 if facility $f$, belonging to firm $j$ in sector $i$ and located in tract $l$, releases any pollutants at time $t$; otherwise, it is 0 . Our main variable of interest is the board's past environmental performance (denoted by $B$ ) which is measured using the board's past average pollution ratio and the range of the board's relative pollution degree centrality. Recall that pollution ratio captures the board's past environmental performance while the range of the board's relative pollution

\footnotetext{
${ }^{12}$ Considering the goodness of fit of the Bayesian estimates, the trace plot of the constant demonstrates good mixing. The posterior distribution of the constant is normal, as is expected for the specified likelihood and prior distributions. These figures are available upon request.
} 
degree centrality captures the diversity of the board. We also control for firm size proxied by the number of plants it owns in a given year, and a firm's influence in the market using the firm's eigenvector centrality. Following Khanna et al. (1998), we include a listed firm dummy to capture the fact that publicly traded companies might behave differently regarding environmental pressure. ${ }^{13}$ In the same spirit, we consider a BoardEx dummy, which is equal to 1 if the facility belongs to a firm present in the BoardEx data (i.e., a firm with a board of directors). Note that a firm in BoardEx can be listed or not. $C$ contains all firm-level variables, $F$ controls for facility-level information. We include total industrial toxicity $(M)$ to capture industrial heterogeneity.

A facility's probability to pollute depends on the demographic and geographic characteristics of the area in which it is located. We, therefore, include a set of tract-level variables $(L)$. The demographic characteristics include median household income, minority ratio, college-education ratio, population density, and an indicator for facilities siting in a special tract. Regarding the geographical characteristics, we control for tracts that are part of an MSA, urban county, rural county, and coastal county, in addition to counties located along the border with Canada and Mexico.

We estimate a facility's probability of polluting using a simple probit model, which takes the following form:

$$
\text { pollute }_{f, j, i, l, t}=B_{j, t-1}^{\prime} \omega+C_{j, t-1}^{\prime} \zeta+F_{f, t-1}^{\prime} \gamma+\chi M_{i, t}+L_{l, t}^{\prime} \nu+\alpha_{f}+\tau_{t}+\mu_{f, j, i, l, t}
$$

where facility $f$ belongs to firm $j$ from industry $i$, in location $l$ at time $t$.

It is possible that the board's past environmental characteristics are endogenous. Hence, we first calculate the probability of each member being on the board in the current year using estimates from Table 3 (Column 1) in the network formation analysis. Next, we weigh each director's pollution ratio by their calculated probability of being a member of the board in a given firm at a given time. The expected board's average pollution ratio is obtained by computing the average of these ratios. We follow similar steps and create a firm-level expected range of the board's relative pollution degree centrality.

Table 4 presents the marginal effects associated with the probit estimation of equation (2). Our results for all facilities in Columns 1 and 2 indicate that, if a board has a poor past pollution record, then it leads to a significantly higher probability of future

\footnotetext{
${ }^{13}$ In our facility- and board-level regressions, it is possible to use a listed dummy because observations are not at the director level, but collapsed at the firm or board level.
} 
polluting incidents (testable hypothesis 4). By contrast, having a diverse board leads to a lower probability of pollution incidents (testable hypothesis 5). Even though firms will try to hire directors who share characteristics with their existing board members, this last result shows that, once appointed, board diversity in terms of environmental records has a positive impact on a firm's environmental performance. If the facility belongs to an industry reporting large amounts of toxic releases, then the facility has a higher probability of release in any given year. Listed firms or firms in BoardEx have a lower probability of polluting compared to non-listed/non-BoardEx firms. This is in line with our conjecture that, because listed firms are accountable to their shareholders, they will be more conscious about their environmental impacts. In Column 2, we re-estimate these results when we endogenize the board's past environmental characteristics. Our qualitative results hold. In Columns 3 and 4, we report the results for BoardEx facilities only. Our main findings are very similar. In Table 5, we estimate these models with facility-level random effects. While the magnitude of the estimated marginal effects has decreased, the qualitative findings have not changed.

\subsubsection{Facility-level toxic releases}

We now turn to the analysis of facility-level toxic releases. Here, our dependent variable is the log of toxicity released and we estimate a linear regression model to evaluate the effect of a board's environmental performance on facilities' toxic releases.

$$
\text { lnRelease }_{f, j, i, l, t}=B_{j, t-1}^{\prime} \lambda+C_{j, t-1}^{\prime} \phi+F_{f, t-1}^{\prime} \vartheta+\xi M_{i, t}+L_{l, t}^{\prime} \varphi+\alpha_{f}+\tau_{t}+\eta_{f, j, i, l, t}
$$

Tables 6 and 7 report the estimated results for all facilities and facilities that belong to a firm in BoardEx, respectively. In Columns 1 and 3, we include firm-level fixed effects while, in Columns 2 and 4, we control for facility-level unobservable heterogeneity by including facility-level fixed effects. Further, Columns 3 and 4 are estimated with expected values of the board's past environmental performance. Note that, while we cannot include the BoardEx dummy because it does not vary through time, we can use the listed dummy. This variable is not necessarily constant for an individual firm. Indeed, our sample covers 17 years and firms can be listed or delisted over time.

Given that a board's average pollution probability and the range of the board's relative pollution degree centrality takes the values between 0 and 1 , it is intuitive to interpret 
these variables considering their marginal effects at the means. Hence, in Table 8, we report the marginal effects at the means for all facilities (Panel A) and BoardEx facilities (Panel B). We observe that a board with a poor average pollution ratio (or its expected value) increases the amount of releases significantly (testable hypothesis 4). As it was the case for the probability of polluting, a diverse board reduces the amount of a toxic release. Similarly, listed firms tend to release less toxic chemicals than non-listed firms (testable hypothesis 5).

In our dataset, many firms are not reporting any toxic release in a given year. As a robustness check, we have left-censored the data for toxic releases per firm per year and estimated our empirical models using censored regression techniques. We present these results in Table A.7. As a reference point, in Columns 1 and 4, we report linear regression results with industry controls. In Columns 2 and 5, we report results from censored regression results similar to the ones estimated via linear regression. In Columns 3 and 6 , we present censored regression results with facility-level random effects controlling for facility-level unobservable heterogeneity. We report the results for all facilities in Panel A and for BoardEx firms in Panel B. Our qualitative results hold.

\section{Conclusion}

This paper is the first study to analyze director network formation in firms reporting toxic releases to the TRI Program. Studying director appointments allows us to endogenize the effect of directors' environmental performance when analyzing their impact on facility-level pollution probability and toxic releases. We build a comprehensive dataset on director-firm network and toxic releases in North America between 2000 and 2017.

Our analysis provides some important insights on the role of corporate governance structure in internalizing increasing environmental pressures and affecting firms' environmental behavior. We show that firms are more likely to appoint candidates who are similar to their existing board directors. These similarities include environmental performance and influence. Firms are also more willing to appoint more experienced directors. Interestingly, when a director becomes influential, poor environmental performance will reduce their probability of being appointed. This implies that a director's previous environmental performance is a key factor that firms take into account when they appoint a new director.

Additionally, our study shows that directors' previous environmental performance af- 
fects their current facilities' environmental performances. Appointing directors with good environmental performance will help improve a firm's environmental performance in terms of lowering polluting probability and the amount of toxic chemicals released. This last result suggests that the market could exert pressure on the influential directors to be "greener," which will have a spillover effect as influential directors spread their environmental performance via their networks. The range of the board's relative environmental performance implies that a more diverse board can also help improve a firm's environmental performance. 


\section{References}

Berrone, P. and Gomez-Mejia, L. R. (2009). Environmental performance and executive compensation: An integrated agency-institutional perspective. Academy of Management Journal, 52(1):103-126.

Cai, Y. and Sevilir, M. (2012). Board connections and M\&A transactions. Journal of Financial Economics, 103(2):327-349.

Casadesus-Masanell, R., Crooke, M., Reinhardt, F., and Vasishth, V. (2009). Households' willingness to pay for "green" goods: evidence from Patagonia's introduction of organic cotton sportswear. Journal of Economics \& Management Strategy, 18(1):203-233.

Chen, R., Dyball, M. C., and Wright, S. (2009). The link between board composition and corporate diversification in Australian corporations. Corporate Governance: An International Review, 17(2):208-223.

Christakis, N., Fowler, J., Imbens, G. W., and Kalyanaraman, K. (2020). An empirical model for strategic network formation. In Graham, B. and Áureo de Paula, editors, The Econometric Analysis of Network Data - Chapter 6, pages 123-148. Academic Press.

Chuluun, T., Prevost, A., and Upadhyay, A. (2017). Firm network structure and innovation. Journal of Corporate Finance, 44:193-214.

CNN (2021). Activist investor ousts at least two Exxon directors in historic win for pro-climate campaign. https://edition.cnn.com/2021/05/26/business/ exxon-annual-meeting-climate-oil/index.html. Accessed: 2021-05-27.

Commission, E. (2012). Action Plan: European Company Law and Corporate Governancea Modern Legal Framework for More Engaged Shareholders and Sustainable Companies: Communication from the Commission to the European Parliament, the Council, the European Economic and Social Committee and the Committee of the Regions:(Text with EEA Relevance). Publications Office of the European Union.

De Silva, D. G., Gertsberg, M., Kosmopoulou, G., and Pownall, R. A. (2020). Evolution of a Dealer Trading Network and its Effects on Art Auction Prices. Working paper: Maastricht University.

De Silva, D. G., Hubbard, T. P., and Schiller, A. R. (2016). Entry and exit patterns of "Toxic" firms. American Journal of Agricultural Economics, 98(3):881-909. 
De Silva, D. G., McComb, R. P., Schiller, A. R., and Slechten, A. (2021). Firm Behavior and Pollution in Small Geographies. European Economic Review, page 103742.

De Villiers, C., Naiker, V., and Van Staden, C. J. (2011). The effect of board characteristics on firm environmental performance. Journal of Management, 37(6):1636-1663.

Dixon-Fowler, H. R., Ellstrand, A. E., and Johnson, J. L. (2017). The role of board environmental committees in corporate environmental performance. Journal of Business Ethics, 140(3):423-438.

Eichholtz, P., Kok, N., and Quigley, J. M. (2010). Doing well by doing good? Green office buildings. American Economic Review, 100(5):2492-2509.

Ferrero-Ferrero, I., Fernández-Izquierdo, M. Á., and Muñoz-Torres, M. J. (2015). Integrating sustainability into corporate governance: An empirical study on board diversity. Corporate Social Responsibility and Environmental Management, 22(4):193-207.

Fracassi, C. and Tate, G. (2012). External networking and internal firm governance. The Journal of Finance, 67(1):153-194.

García Martín, C. J. and Herrero, B. (2020). Do board characteristics affect environmental performance? A study of EU firms. Corporate Social Responsibility and Environmental Management, 27(1):74-94.

Gelman, A. (2004). Parameterization and Bayesian Modeling. Journal of the American Statistical Association, 99(466):537-545.

Hamilton, J. T. (1995). Pollution as news: Media and stock market reactions to the toxics release inventory data. Journal of environmental economics and management, 28(1):98-113.

Hillman, A. J. and Dalziel, T. (2003). Boards of directors and firm performance: Integrating agency and resource dependence perspectives. Academy of Management Review, 28(3):383-396.

Homroy, S. and Slechten, A. (2019). Do Board Expertise and Networked Boards Affect Environmental Performance? Journal of Business Ethics, 158(1):269-292.

Jackson, M. O. (2010). Social and economic networks. Princeton University Press. 
Jackson, M. O. and Pernoud, A. (2019). Distorted investment incentives, regulation, and equilibrium multiplicity in a model of financial networks. Regulation, and Equilibrium Multiplicity in a Model of Financial Networks (March 1, 2019).

Jackson, M. O. and Pernoud, A. (2020). Systemic Risk in Financial Networks: A Survey. Available at SSRN.

Khanna, M., Quimio, W. R. H., and Bojilova, D. (1998). Toxics release information: A policy tool for environmental protection. Journal of Environmental Economics and Management, 36(3):243-266.

Kroll, M., Walters, B. A., and Wright, P. (2008). Board vigilance, director experience, and corporate outcomes. Strategic Management Journal, 29(4):363-382.

Lazear, E. P. (1998). Personnel Economics for managers. Wiley New York.

Li, T. and Zheng, X. (2009). Entry and competition effects in first-price auctions: theory and evidence from procurement auctions. The Review of Economic Studies, 76(4):13971429.

Lu, J. and Herremans, I. M. (2019). Board gender diversity and environmental performance: An industries perspective. Business Strategy and the Environment, 28(7):14491464.

Lux, T. (2015). Emergence of a core-periphery structure in a simple dynamic model of the interbank market. Journal of Economic Dynamics and Control, 52(C):A11-A23.

Maxwell, J. W., Lyon, T. P., and Hackett, S. C. (2000). Self-regulation and social welfare: The political economy of corporate environmentalism. The Journal of Law and Economics, 43(2):583-618.

McKendall, M., Sánchez, C., and Sicilian, P. (1999). Corporate governance and corporate illegality: The effects of board structure on environmental violations. The International Journal of Organizational Analysis, 7(3):201-223.

Ortiz-de Mandojana, N., Aragón-Correa, J. A., Delgado-Ceballos, J., and Ferrón-Vúlchez, V. (2012). The effect of director interlocks on firms' adoption of proactive environmental strategies. Corporate Governance: An International Review, 20(2):164-178.

Pfeffer, J. and Salancik, G. R. (2003). The external control of organizations: A resource dependence perspective. Stanford University Press. 
Post, C., Rahman, N., and Rubow, E. (2011). Green governance: Boards of directors' composition and environmental corporate social responsibility. Business \& Society, 50(1):189-223.

Sorkin, A. R. (2020). BlackRock C.E.O. Larry Fink: Climate crisis will reshape finance. New York Times, https://www.nytimes.com/2020/01/14/business/dealbook/larry-finkblackrock-climate-change.html.

Turban, D. B. and Greening, D. W. (1997). Corporate social performance and organizational attractiveness to prospective employees. Academy of Management Journal, $40(3): 658-672$.

Walls, J. L., Berrone, P., and Phan, P. H. (2012). Corporate governance and environmental performance: Is there really a link? Strategic Management Journal, 33(8):885-913.

Westphal, J. D. and Zajac, E. J. (2013). A behavioral theory of corporate governance: Explicating the mechanisms of socially situated and socially constituted agency. Academy of Management Annals, 7(1):607-661.

Zhuang, Y., Chang, X., and Lee, Y. (2018). Board Composition and Corporate Social Responsibility Performance: Evidence from Chinese Public Firms. Sustainability, 10(8):2752.

Zona, F., Gomez-Mejia, L. R., and Withers, M. C. (2018). Board interlocks and firm performance: Toward a combined agency-resource dependence perspective. Journal of Management, 44(2):589-618. 
Figure 1: Directors' sub-network with a distance of 2

This graph shows a sub-network focusing on two directors among all directors who are connected to at least one TRI firm for the year 2017. Red nodes represent the two directors. The brown nodes represent polluting firms, and the green nodes represent clean firms. Blue nodes represent the other directors. A distance of two means that we are representing all the nodes that are at a distance of at most two (two edges) of the two directors (red nodes). Clean firms are defined as firms with no facilities releasing toxic chemicals above the TRI threshold for a given year. This sub-network includes nine firms-three polluting firms and six clean firms-with 69 directors. In our setting, directors' environmental performance will be a function of the past environmental performance of the firms they are connected. In this example, both directors have two 'pollution links' as they are connected to two polluting firms. However, one director serves on the board of three firms, while the other is connected to seven firms. The director serving on the board of seven firms will be considered as having a better environmental performance.

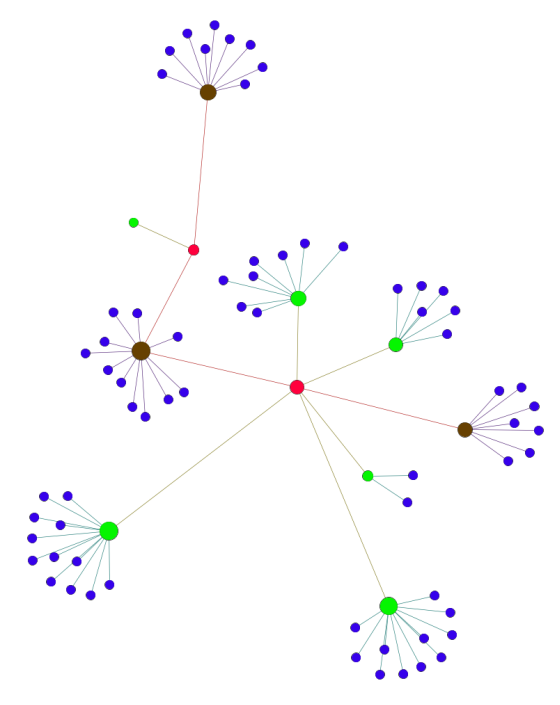


Figure 2: Directors' sub-network with a distance of 4

Figure 2 presents the sub-network of the two most influential directors (same directors as in Figure 1) among all TRI-related directors (represented by the red nodes) for the year 2017. Nodes' color notations are the same as in Figure 1. Compared to Figure 1, we expand the sub-network to include all the nodes at a distance of at most four from the two most influential directors. With this increase in distance, the number of nodes increases by 1,316, and the number of edges increases by 1,815. The comparison of Figures 1 and 2 provides some insight into the complexity and size of the network.

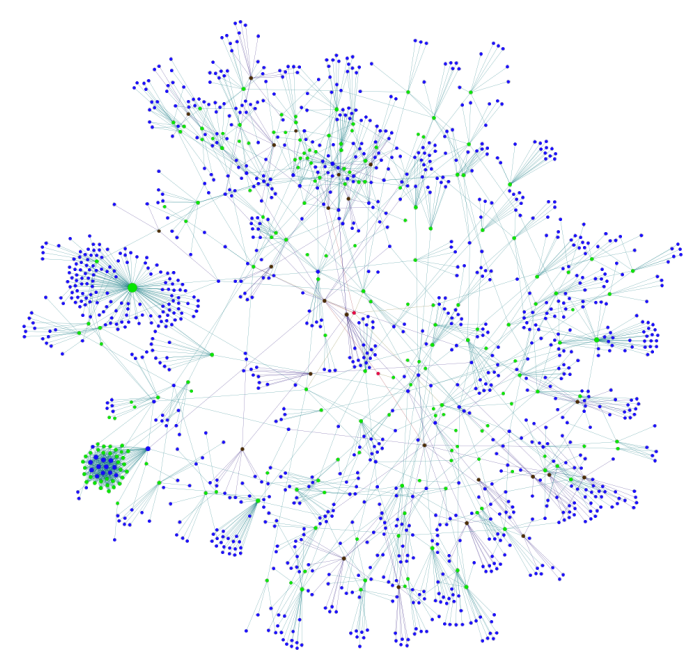


Table 1: Matched summary statistics for regression sample: 2001-2017

Column 1 reports summary statistics for all the facilities used in the analysis. Column 2 and Column 3 show the information on facilities belonging to a firm with and without directors, respectively. All tracts are based on 2010 US Census data. A 'special tract' is defined as a tract that does not have any demographic information disclosed by the US Census. All the director's network measures in Column 3 are equal to zero because we don't have board information recorded in BoardEx for those facilities. The Board's average pollution ratio is the average of the director's pollution ratio. The expected board's average pollution ratio is obtained by weighing each director's pollution ratio by their calculated probability of being a director in a given firm at a given time and computing the average of these ratios. Using the same approach, we create a firm-level expected range of the board's relative pollution degree centrality that captures the board diversity in terms of environmental performance.

\begin{tabular}{|c|c|c|c|}
\hline \multirow[t]{3}{*}{ Variable } & \multicolumn{3}{|c|}{ Mean or count } \\
\hline & \multicolumn{3}{|c|}{ Facilities } \\
\hline & All & With directors & Without directors \\
\hline Total number of observations (facility level) & 582,722 & 288,277 & 294,445 \\
\hline Number of unique firms & 19,035 & 2,873 & 16,162 \\
\hline Number of unique facilities & 40,990 & 18,927 & 22,063 \\
\hline Unique number of directors & 17,224 & 17,224 & 0 \\
\hline Number of unique tracts (locations) & 18,183 & 8,420 & 9,763 \\
\hline \multirow[t]{2}{*}{ Probability of polluting } & 0.532 & 0.530 & 0.534 \\
\hline & $(0.499)$ & $(0.499)$ & $(0.499)$ \\
\hline \multirow[t]{2}{*}{ Total toxicity released by facility (in thousands of pounds) } & $121,538.2$ & $151,601.5$ & $92,104.72$ \\
\hline & $(4,214,303)$ & $(2,212,775)$ & $(5,509,371)$ \\
\hline \multirow[t]{2}{*}{ Board's average pollution ratio } & 0.178 & 0.359 & 0 \\
\hline & $(0.273)$ & $(0.293)$ & \\
\hline \multirow[t]{2}{*}{ The range of the board's relative pollution degree centrality } & 0.215 & 0.435 & 0 \\
\hline & $(0.355)$ & $(0.399)$ & \\
\hline \multirow[t]{2}{*}{$\mathrm{E}[$ Board's average pollution ratio] } & 0.091 & 0.182 & 0 \\
\hline & $(0.139)$ & $(0.149)$ & \\
\hline \multirow[t]{2}{*}{$\mathrm{E}[$ The range of the board's relative pollution degree centrality] } & 0.110 & 0.221 & 0 \\
\hline & $(0.181)$ & $(0.203)$ & \\
\hline \multirow[t]{2}{*}{ Firm's influence $\left(10^{-4}\right)$} & 0.057 & 0.114 & 0 \\
\hline & $(4.793)$ & $(6.813)$ & \\
\hline \multirow[t]{2}{*}{ Number of plants per firm } & 27.692 & 51.082 & 4.791 \\
\hline & $(58.822)$ & 76.018 & 11.390 \\
\hline \multirow[t]{2}{*}{ Median household income } & $56,484.18$ & $56,559.55$ & $56,410.39$ \\
\hline & $(23,104.16)$ & $(23,293.22)$ & $(22,917.36)$ \\
\hline \multirow[t]{2}{*}{ Minority ratio } & 0.231 & 0.232 & 0.229 \\
\hline & $(0.238)$ & $(0.237)$ & $(0.239)$ \\
\hline \multirow[t]{2}{*}{ College ratio } & 0.194 & 0.195 & 0.192 \\
\hline & $(0.172)$ & $(0.175)$ & $(0.168)$ \\
\hline \multirow[t]{2}{*}{ Population density } & $1,422.282$ & $1,225.626$ & $1,614.818$ \\
\hline & $(2,538.237)$ & $(2,156.295)$ & $(2,850.125)$ \\
\hline \multirow[t]{2}{*}{ Facility belong to a firm with directors (BoardEx firm) } & 0.495 & 1 & 0 \\
\hline & $(0.500)$ & & \\
\hline \multirow[t]{2}{*}{ Facility belong to a listed firm } & 0.183 & 0.370 & 0 \\
\hline & $(0.387)$ & $(0.483)$ & \\
\hline \multirow[t]{2}{*}{ Probability of locating in a special tract } & 0.014 & 0.016 & 0.012 \\
\hline & $(0.117)$ & $(0.127)$ & $(0.107)$ \\
\hline \multirow[t]{2}{*}{ The probability of a plant located in an MSA County } & 0.760 & 0.751 & 0.769 \\
\hline & $(0.427)$ & $(0.432)$ & $(0.421)$ \\
\hline \multirow[t]{2}{*}{ The probability of a plant located in an urban County } & 0.222 & 0.231 & 0.214 \\
\hline & $(0.416)$ & $(0.421)$ & $(0.410)$ \\
\hline \multirow[t]{2}{*}{ The probability of a plant located in a costal County } & 0.173 & 0.175 & 0.171 \\
\hline & $(0.378)$ & $(0.380)$ & $(0.376)$ \\
\hline \multirow[t]{2}{*}{ The probability of being located in a Mexico border County } & 0.010 & 0.010 & 0.009 \\
\hline & $(0.096)$ & $(0.099)$ & $(0.093)$ \\
\hline \multirow[t]{2}{*}{ The probability of being located in a Canada border County } & 0.042 & 0.038 & 0.046 \\
\hline & $(0.200)$ & $(0.191)$ & $(0.209)$ \\
\hline
\end{tabular}

Standard deviations are in parentheses. 
Table 2: Summary statistics of variables used in the network formation analysis

This table reports summary statistics for the variables used in the network formation analysis. We create a pool of candidates based on homophily measures and identify a possible 8,487,170 director-firm pairs for all TRI-reporting firms with directors for all years. On average, this corresponds to about 300 potential candidates per firm in a given. Column 1 presents summary statistics for all firms, while Column 2 provides summary statistics for listed firms.

\begin{tabular}{|c|c|c|}
\hline \multirow[t]{3}{*}{ Variable } & \multicolumn{2}{|c|}{ Mean } \\
\hline & All firms & Listed firms \\
\hline & (1) & $(2)$ \\
\hline \multirow[t]{2}{*}{ Probability of creating a link } & 0.019 & 0.026 \\
\hline & $(0.137)$ & $(0.160)$ \\
\hline \multirow[t]{2}{*}{ Director's past pollution ratio } & 0.446 & $(0.488)$ \\
\hline & $(0.386)$ & $(0.368)$ \\
\hline \multirow[t]{2}{*}{ Director's influence } & 0.0002 & 0.0002 \\
\hline & $(0.014)$ & $(0.014)$ \\
\hline \multirow[t]{2}{*}{ Director's past pollution ratio $\times$ director's influence } & 0.0001 & 0.0001 \\
\hline & $(0.009)$ & $(0.010)$ \\
\hline \multirow[t]{2}{*}{ Firm's influence } & 0.0001 & 0.00003 \\
\hline & $(0.0021)$ & $(0.0014)$ \\
\hline \multirow{2}{*}{$\begin{array}{l}\text { Difference in director's relative pollution degree centrality respect to } \\
\text { other board members average relative pollution degree centrality }\end{array}$} & 0.324 & 0.338 \\
\hline & $(0.299)$ & $(0.249)$ \\
\hline \multirow{2}{*}{$\begin{array}{l}\text { Difference in director's pollution ratio respect to firm's } \\
\text { pollution ratio }{ }^{a}\end{array}$} & 0.322 & 0.323 \\
\hline & $(0.312)$ & $(0.280)$ \\
\hline \multirow[t]{2}{*}{ Difference in director's influence and firms's influence ${ }^{a}$} & 0.0003 & 0.0003 \\
\hline & $(0.014)$ & $(1.015)$ \\
\hline \multirow[t]{2}{*}{ Market exposure in years (number of years in BoardEx) } & 5.545 & 5.935 \\
\hline & $(4.506)$ & $(4.578)$ \\
\hline
\end{tabular}

${ }^{a}$ The homophily measures are given in absolute values. Standard deviations are in parentheses. 
Table 3: Bayesian estimates of network formation parameters

The table displays the means of the posterior distributions for each network parameter affecting the probability of forming a link between directors and firms at time $t$. The dependent variable is equal to 1 if a director, in year $t$, becomes a member of the board. The independent variables used are lagged by one year. The model was estimated using Bayesian MCMC technique based on a hybrid Metropolis-Hastings algorithm with Gibbs sampling based on Equation (1). We use uniform priors for the regression coefficients and an inverse gamma prior with shape and scale parameters of 0.1 and 0.1 for the error variance. In all our Bayesian estimates, we use 10,000 iterations and omit the first 2,500 to mitigate possible start-up effects. Column 1 reports the regression results for all firms in our sample, and Column 2 reports the regression results for listed firms only. Influence is measured by eigenvector centrality measure. A candidate's relative pollution degree centrality is calculated as the proportion of pollution links relative to their total number of links.

\begin{tabular}{|c|c|c|c|}
\hline \multirow[t]{3}{*}{ Parameter } & \multirow[t]{3}{*}{ Variable } & \multicolumn{2}{|c|}{ Mean of the posterior distribution } \\
\hline & & All firms & Listed firms \\
\hline & & $(1)$ & $(2)$ \\
\hline \multirow[t]{2}{*}{$\rho_{1}$} & Director's past pollution ratio $_{t-1}$ & -0.0002 & -0.0139 \\
\hline & & {$[-0.0004,0.0001]$} & {$[-0.0144,-0.0134]$} \\
\hline \multirow[t]{2}{*}{$\beta_{1}$} & Director's influence $t-1$ & 0.0999 & 0.0997 \\
\hline & & {$[0.0994,0.1003]$} & {$[0.0917,0.1078]$} \\
\hline \multirow[t]{2}{*}{$\beta_{2}$} & Director's past pollution ratiot $t-1 \times$ director's influence $t-1$ & -0.0529 & -0.0627 \\
\hline & & {$[-0.0549,-0.0500]$} & {$[-0.0692,-0.0555]$} \\
\hline \multirow[t]{2}{*}{$\beta_{3}$} & Firm's influence $t-1$ & 0.1200 & 0.4062 \\
\hline & & {$[0.1081,0.1284]$} & {$[0.3849,0.4275]$} \\
\hline \multirow[t]{2}{*}{$\psi_{1}$} & Difference in director's relative pollution degree centrality respect to & -0.0295 & -0.0454 \\
\hline & other board members average relative pollution degree centrality ${ }_{t-1}^{a}$ & {$[-0.0298,-0.0291]$} & {$[-0.0461,-0.0447]$} \\
\hline \multirow[t]{2}{*}{$\psi_{2}$} & Difference in director's pollution ratio respect to firm's & -0.0475 & -0.0763 \\
\hline & pollution ratio ${ }_{t-1}^{a}$ & {$[-0.0478,-0.0475]$} & {$[-0.0769,-0.0757]$} \\
\hline \multirow[t]{2}{*}{$\psi_{3}$} & Difference in director's influence and firm's influence $t-1$ & -0.0703 & -0.0707 \\
\hline & & {$[-0.0717,-0.0687]$} & {$[-0.0771,-0.0646]$} \\
\hline \multirow[t]{2}{*}{$\delta_{1}$} & $\log ($ Market exposure in years) & 0.0025 & 0.0033 \\
\hline & & {$[0.0024,0.0026]$} & {$[0.0030,0.0035]$} \\
\hline$\gamma_{1}$ & Trend & Yes & Yes \\
\hline \multicolumn{2}{|c|}{ Number of observations } & $8,487,170$ & $3,173,029$ \\
\hline \multicolumn{2}{|c|}{ Log marginal likelihood } & $4,921,367$ & $1,352,932$ \\
\hline
\end{tabular}

${ }^{a}$ The homophily measures are given in absolute values. $95 \%$ Credible intervals are in parentheses. 
Table 4: Pollution probabilities

This table presents the marginal effects associated with the probit estimation of Equation (2). All regressions include log number of plants per firm, log of median household income, minority ratio, college ratio, $\log$ of population density, and indicator for facilities siting in a special tract. Columns 1 and 2 report results for all facilities, and Columns 3 and 4 report the results for BoardEx facilities only. In Columns 2 and 4 , we re-estimate these results when we endogenize the board's past environmental performance. We weigh each director's pollution ratio by their calculated probability of being a board member in a given firm at a given time from Column 1 of Table 3. The expected board's average pollution ratio is obtained by computing the average of these ratios. Using a similar technique, we create a firm-level expected range of the board's relative pollution degree centrality.

\begin{tabular}{|c|c|c|c|c|}
\hline \multirow[t]{3}{*}{ Variable } & \multicolumn{4}{|c|}{ Probability of polluting $j t$} \\
\hline & \multicolumn{2}{|c|}{ All facilities } & \multicolumn{2}{|c|}{ BoardEx facilities } \\
\hline & $(1)$ & $(2)$ & $(3)$ & $(4)$ \\
\hline Board's average pollution ratio $_{j, t-1}$ & $\begin{array}{c}0.480 * * * \\
(0.004)\end{array}$ & & $\begin{array}{c}0.483^{* * *} \\
(0.004)\end{array}$ & \\
\hline $\begin{array}{l}\text { The range of the board's relative pollution } \\
\text { degree centrality } j, t-1\end{array}$ & $\begin{array}{c}-0.206^{* * *} \\
(0.003)\end{array}$ & & $\begin{array}{c}-0.178^{* * *} \\
(0.003)\end{array}$ & \\
\hline $\mathrm{E}[\text { Board's average pollution ratio }]_{j, t}$ & & $\begin{array}{c}0.943^{* * *} \\
(0.008)\end{array}$ & & $\begin{array}{c}0.950^{* * *} \\
(0.008)\end{array}$ \\
\hline $\begin{array}{l}\mathrm{E}[\text { The range of the board's relative pollution } \\
\text { degree centrality }]_{j, t-1}\end{array}$ & & $\begin{array}{c}-0.406 * * * \\
(0.006)\end{array}$ & & $\begin{array}{c}-0.350^{* * *} \\
(0.007)\end{array}$ \\
\hline Firm's influence $_{j, t-1}$ & $\begin{array}{c}0.129 \\
(1.501)\end{array}$ & $\begin{array}{c}0.123 \\
(1.501)\end{array}$ & $\begin{array}{l}-1.036 \\
(1.477)\end{array}$ & $\begin{array}{l}-1.042 \\
(1.476)\end{array}$ \\
\hline Log of total industrial toxicity $i, t$ & $\begin{array}{c}0.099^{* * *} \\
(0.004)\end{array}$ & $\begin{array}{c}0.099^{* * *} \\
(0.004)\end{array}$ & $\begin{array}{c}0.103^{* * *} \\
(0.005)\end{array}$ & $\begin{array}{c}0.103^{* * *} \\
(0.005)\end{array}$ \\
\hline Facility belongs to a BoardEx firm $i, t$ & $\begin{array}{c}-0.112^{* * *} \\
(0.002)\end{array}$ & $\begin{array}{c}-0.112^{* * *} \\
(0.002)\end{array}$ & & \\
\hline Facility belongs to a listed firm $_{i, t}$ & $\begin{array}{c}-0.036^{* * *} \\
(0.002)\end{array}$ & $\begin{array}{c}-0.036^{* * *} \\
(0.002)\end{array}$ & $\begin{array}{c}-0.032^{* * *} \\
(0.002)\end{array}$ & $\begin{array}{c}-0.032^{* * *} \\
(0.002)\end{array}$ \\
\hline Located in a special tract & Yes & Yes & Yes & Yes \\
\hline MSA, Urban, and Costal County effects & Yes & Yes & Yes & Yes \\
\hline Located in a county that border Mexico or Canada & Yes & Yes & Yes & Yes \\
\hline Industry effects & Yes & Yes & Yes & Yes \\
\hline Time effects & Yes & Yes & Yes & Yes \\
\hline Observations & 582,722 & 582,722 & 288,277 & 288,277 \\
\hline Wald $\chi^{2}$ & 35,848 & 35,868 & 27,770 & 27,796 \\
\hline Log likelihood & $-382,584$ & $-382,571$ & $-183,699$ & $-183,684$ \\
\hline
\end{tabular}


Table 5: Pollution probabilities - with facility level random effects

This table presents the marginal effects associated with the probit estimation of Equation (2). All regressions include log number of plants per firm, log of median household income, minority ratio, college ratio, $\log$ of population density, and indicator for facilities siting in a special tract. Columns 1 and 2 report results for all facilities, and Columns 3 and 4 report the results for BoardEx facilities only. In Columns 2 and 4 , we re-estimate these results when we endogenize the board's past environmental performance. We weigh each director's pollution ratio by their calculated probability of being a board member in a given firm at a given time from Column 1 of Table 3. The expected board's average pollution ratio is obtained by computing the average of these ratios. Using a similar technique, we create a firm-level expected range of the board's relative pollution degree centrality.

\begin{tabular}{|c|c|c|c|c|}
\hline \multirow[t]{3}{*}{ Variable } & \multicolumn{4}{|c|}{ Probability of polluting $j t$} \\
\hline & \multicolumn{2}{|c|}{ All facilities } & \multicolumn{2}{|c|}{ BoardEx facilities } \\
\hline & $(1)$ & $(2)$ & $(3)$ & $(4)$ \\
\hline Board's average pollution ratio $j, t-1$ & $\begin{array}{c}0.287^{* * *} \\
(0.004)\end{array}$ & & $\begin{array}{c}0.286^{* * *} \\
(0.004)\end{array}$ & \\
\hline $\begin{array}{l}\text { The range of the board's relative pollution } \\
\text { degree centrality } j, t-1\end{array}$ & $\begin{array}{c}-0.054^{* * *} \\
(0.003)\end{array}$ & & $\begin{array}{c}-0.041^{* * *} \\
(0.003)\end{array}$ & \\
\hline $\mathrm{E}[\text { Board's average pollution ratio }]_{j, t}$ & & $\begin{array}{c}0.565^{* * *} \\
(0.008)\end{array}$ & & $\begin{array}{c}0.562^{* * *} \\
(0.008)\end{array}$ \\
\hline $\begin{array}{l}\mathrm{E}[\text { The range of the board's relative pollution } \\
\text { degree centrality }]_{j, t-1}\end{array}$ & & $\begin{array}{c}-0.106^{* * *} \\
(0.007)\end{array}$ & & $\begin{array}{c}-0.080 * * * \\
(0.007)\end{array}$ \\
\hline Firm's influence $_{j, t-1}$ & $\begin{array}{c}0.911 \\
(1.604)\end{array}$ & $\begin{array}{c}0.903 \\
(1.604)\end{array}$ & $\begin{array}{c}0.812 \\
(1.547)\end{array}$ & $\begin{array}{c}0.804 \\
(1.547)\end{array}$ \\
\hline $\log$ of total industrial toxicity $i, t$ & $\begin{array}{c}0.102^{* * *} \\
(0.002)\end{array}$ & $\begin{array}{c}0.102^{* * *} \\
(0.002)\end{array}$ & $\begin{array}{c}0.095^{* * *} \\
(0.003)\end{array}$ & $\begin{array}{c}0.095^{* * *} \\
(0.003)\end{array}$ \\
\hline Facility belongs to a BoardEx firm $_{i, t}$ & $\begin{array}{c}-0.098^{* * *} \\
(0.005)\end{array}$ & $\begin{array}{c}-0.098^{* * *} \\
(0.005)\end{array}$ & & \\
\hline Facility belongs to a listed firm $i, t$ & $\begin{array}{c}-0.035^{* * *} \\
(0.004)\end{array}$ & $\begin{array}{c}-0.035^{* * *} \\
(0.004)\end{array}$ & $\begin{array}{c}-0.033^{* * *} \\
(0.004)\end{array}$ & $\begin{array}{c}-0.033^{* * *} \\
(0.004)\end{array}$ \\
\hline Facility level random effects & Yes & Yes & Yes & Yes \\
\hline MSA, Urban, and Costal County effects & Yes & Yes & Yes & Yes \\
\hline Located in a county that border Mexico or Canada & Yes & Yes & Yes & Yes \\
\hline Industry effects & Yes & Yes & Yes & Yes \\
\hline Time effects & Yes & Yes & Yes & Yes \\
\hline Observations & 582,722 & 582,722 & 288,277 & 288,277 \\
\hline Wald $\chi^{2}$ & 11,936 & 11,948 & 8,753 & 8,768 \\
\hline Log likelihood & $-246,373$ & $-246,365$ & $-114,886$ & $-114,877$ \\
\hline
\end{tabular}


Table 6: Regression results for total release - all facilities

This table reports the OLS regression results for all facilities. The dependent variable is the log of total toxic material released by a facility in a given year. All regressions include log number of plants per firm, $\log$ of median household income, minority ratio, college ratio, log of population density, and indicator for facilities siting in a special tract. In Columns 1 and 3, we include firm-level fixed effects; while, in Columns 2 and 4, we control for facility-level unobservable heterogeneities by including facility-level fixed effects. Further, Columns 3 and 4 are estimated with expected values of the board's past environmental performance.

\begin{tabular}{|c|c|c|c|c|}
\hline \multirow[t]{2}{*}{ Variable } & \multicolumn{4}{|c|}{ Log of toxicity released $j t$} \\
\hline & (1) & $(2)$ & $(3)$ & (4) \\
\hline Board's average pollution ratio $j, t-1$ & $\begin{array}{c}1.326^{* * *} \\
(0.139)\end{array}$ & $\begin{array}{c}1.575^{* * *} \\
(0.124)\end{array}$ & & \\
\hline $\begin{array}{l}\text { The range of the board's relative pollution } \\
\text { degree centrality } j, t-1\end{array}$ & $\begin{array}{c}-0.197^{* *} \\
(0.086)\end{array}$ & $\begin{array}{c}-0.166^{* *} \\
(0.082)\end{array}$ & & \\
\hline $\mathrm{E}[\text { Board's average pollution ratio }]_{j, t-1}$ & & & $\begin{array}{c}2.609^{* * *} \\
(0.274)\end{array}$ & $\begin{array}{c}3.098^{* * *} \\
(0.244)\end{array}$ \\
\hline $\begin{array}{l}\mathrm{E} \text { [The range of the board's relative pollution } \\
\text { degree centrality }]_{j, t-1}\end{array}$ & & & $\begin{array}{c}-0.382^{* *} \\
(0.170)\end{array}$ & $\begin{array}{c}-0.321^{* *} \\
(0.163)\end{array}$ \\
\hline Firm's influence $_{j, t-1}$ & $\begin{array}{c}25.410 \\
(33.238)\end{array}$ & $\begin{array}{c}24.806 \\
(33.650)\end{array}$ & $\begin{array}{c}25.366 \\
(33.240)\end{array}$ & $\begin{array}{c}24.753 \\
(33.653)\end{array}$ \\
\hline $\log$ of total industrial toxicity $i, t$ & $\begin{array}{c}0.351^{* * *} \\
(0.028)\end{array}$ & $\begin{array}{c}0.269^{* * *} \\
(0.019)\end{array}$ & $\begin{array}{c}0.351^{* * *} \\
(0.028)\end{array}$ & $\begin{array}{c}0.269^{* * *} \\
(0.019)\end{array}$ \\
\hline Facility belongs to a listed firm $i, t$ & $\begin{array}{l}-0.240^{*} \\
(0.128)\end{array}$ & $\begin{array}{l}-0.234^{*} \\
(0.128)\end{array}$ & $\begin{array}{c}-0.240^{*} \\
(0.128)\end{array}$ & $\begin{array}{c}-0.234^{*} \\
(0.128)\end{array}$ \\
\hline Firm effects & Yes & & Yes & \\
\hline Facility effects & & Yes & & Yes \\
\hline Located in a special tract & Yes & Yes & Yes & Yes \\
\hline MSA, Urban, and Costal County effects & Yes & Yes & Yes & Yes \\
\hline Located in a county that border Mexico or Canada & Yes & Yes & Yes & Yes \\
\hline Time effects & Yes & Yes & Yes & Yes \\
\hline Observations & 582,722 & 582,722 & 582,722 & 582,722 \\
\hline $\mathrm{R}^{2}$ & 0.462 & 0.725 & 0.462 & 0.725 \\
\hline
\end{tabular}


Table 7: Regression results for total release - BoardEx facilities

This table reports the OLS regression results for facilities that belong to a firm in BoardEx. The dependent variable is the log of total toxins released by a facility in a given year. All regressions include log number of plants per firm, log of median household income, minority ratio, college ratio, log of population density, and indicator for facilities siting in a special tract. In Columns 1 and 3, we include firm-level fixed effects; while, in Columns 2 and 4, we control for facility-level unobservable heterogeneities by including facilitylevel fixed effects. Further, Columns 3 and 4 are estimated with expected values of the board's past environmental performance.

\begin{tabular}{|c|c|c|c|c|}
\hline \multirow[t]{2}{*}{ Variable } & \multicolumn{4}{|c|}{$\log$ of toxicity released $j t$} \\
\hline & $(1)$ & $(2)$ & $(3)$ & (4) \\
\hline Board's average pollution ratio $j, t-1$ & $\begin{array}{c}1.504^{* * *} \\
(0.136)\end{array}$ & $\begin{array}{c}1.742^{* * *} \\
(0.125)\end{array}$ & & \\
\hline $\begin{array}{l}\text { The range of the board's relative pollution } \\
\text { degree centrality } j, t-1\end{array}$ & $\begin{array}{l}-0.107 \\
(0.082)\end{array}$ & $\begin{array}{l}-0.088 \\
(0.079)\end{array}$ & & \\
\hline $\mathrm{E}[\text { Board's average pollution ratio }]_{j, t-1}$ & & & $\begin{array}{c}2.959^{* * *} \\
(0.268)\end{array}$ & $\begin{array}{c}3.425^{* * *} \\
(0.246)\end{array}$ \\
\hline $\begin{array}{l}\mathrm{E} \text { [The range of the board's relative pollution } \\
\text { degree centrality }]_{j, t-1}\end{array}$ & & & $\begin{array}{l}-0.204 \\
(0.163)\end{array}$ & $\begin{array}{l}-0.167 \\
(0.156)\end{array}$ \\
\hline Firm's influence $_{j, t-1}$ & $\begin{array}{c}25.211 \\
(33.289)\end{array}$ & $\begin{array}{c}24.859 \\
(34.123)\end{array}$ & $\begin{array}{c}25.160 \\
(33.293)\end{array}$ & $\begin{array}{c}24.801 \\
(34.128)\end{array}$ \\
\hline Log of total industrial toxicity $i, t$ & $\begin{array}{c}0.384^{* * *} \\
(0.036)\end{array}$ & $\begin{array}{c}0.270^{* * *} \\
(0.032)\end{array}$ & $\begin{array}{c}0.384^{* * *} \\
(0.036)\end{array}$ & $\begin{array}{c}0.270^{* * *} \\
(0.032)\end{array}$ \\
\hline Facility belongs to a listed firm $i, t$ & $\begin{array}{c}-0.272^{* *} \\
(0.133)\end{array}$ & $\begin{array}{c}-0.278^{* *} \\
(0.134)\end{array}$ & $\begin{array}{c}-0.272^{* *} \\
(0.133)\end{array}$ & $\begin{array}{c}-0.278^{* *} \\
(0.135)\end{array}$ \\
\hline Firm effects & Yes & & Yes & \\
\hline Facility effects & & Yes & & Yes \\
\hline Located in a special tract & Yes & Yes & Yes & Yes \\
\hline MSA, Urban, and Costal County effects & Yes & Yes & Yes & Yes \\
\hline Located in a county that border Mexico or Canada & Yes & Yes & Yes & Yes \\
\hline Time effects & Yes & Yes & Yes & Yes \\
\hline Observations & 288,277 & 288,277 & 288,277 & 288,277 \\
\hline $\mathrm{R}^{2}$ & 0.361 & 0.762 & 0.361 & 0.762 \\
\hline
\end{tabular}


Table 8: Regression results for total release - marginal effects at the mean

This table reports the marginal effects at the means for all facilities in Panel A and BoardEx facilities in Panel B. For all facilities, the mean of the board's average pollution ratio is 0.178 , the mean of the range of the board's relative pollution degree centrality is 0.215 , the mean of the expected board's average pollution ratio is 0.091 , the mean of the expected range of the board's relative pollution degree centrality is 0.110 , and the mean of firm's influence is $6.667 \times\left(10^{-6}\right)$. For BoardEx facilities, the mean of the board's average pollution ratio is 0.360 , the mean of the range of the board's relative pollution degree centrality is 0.435 , the mean of the expected board's average pollution ratio is 0.183 , the mean of the expected range of the board's relative pollution degree centrality is 0.221 , and the mean of firm's influence is $1.14 \times\left(10^{-5}\right)$. To calculate the marginal effect of a variable, we multiply the coefficient from the OLS regressions on a facility's total release (shown in Tables 6 and 7 ) of each variable by its corresponding mean.

\begin{tabular}{|c|c|c|c|c|}
\hline \multirow[t]{2}{*}{ Variable } & \multicolumn{4}{|c|}{ Log of toxicity released $j t$} \\
\hline & (1) & $(2)$ & (3) & (4) \\
\hline \multicolumn{5}{|l|}{ Panel A: All facilities } \\
\hline Board's average pollution ratio $_{j, t-1}$ & $\begin{array}{c}0.236^{* * *} \\
(0.025)\end{array}$ & $\begin{array}{l}0.280^{* * *} \\
(0.022)\end{array}$ & & \\
\hline $\begin{array}{l}\text { The range of the board's relative pollution } \\
\text { degree centrality } j, t-1\end{array}$ & $\begin{array}{c}-0.042^{* *} \\
(0.018)\end{array}$ & $\begin{array}{c}-0.036^{* *} \\
(0.018)\end{array}$ & & \\
\hline $\mathrm{E}[\text { Board's average pollution ratio }]_{j, t-1}$ & & & $\begin{array}{c}0.236^{* * *} \\
(0.025)\end{array}$ & $\begin{array}{c}0.280^{* * *} \\
(0.022)\end{array}$ \\
\hline $\begin{array}{l}\mathrm{E}[\text { The range of the board's relative pollution } \\
\text { degree centrality }]_{j, t-1}\end{array}$ & & & $\begin{array}{c}-0.042^{* *} \\
(0.019)\end{array}$ & $\begin{array}{l}-0.035^{*} \\
(0.018)\end{array}$ \\
\hline Firm's influence $_{j, t-1}$ & $\begin{array}{c}0.0001 \\
(0.0002)\end{array}$ & $\begin{array}{c}0.0001 \\
(0.0002)\end{array}$ & $\begin{array}{c}0.0001 \\
(0.0002)\end{array}$ & $\begin{array}{c}0.0001 \\
(0.0002)\end{array}$ \\
\hline \multicolumn{5}{|l|}{ Panel B: BoardEx facilities } \\
\hline Board's average pollution ratio $j, t-1$ & $\begin{array}{c}0.540^{* * *} \\
(0.049)\end{array}$ & $\begin{array}{c}0.626^{* * *} \\
(0.045)\end{array}$ & & \\
\hline $\begin{array}{l}\text { The range of the board's relative pollution } \\
\text { degree centrality } j, t-1\end{array}$ & $\begin{array}{l}-0.047 \\
(0.036)\end{array}$ & $\begin{array}{l}-0.039 \\
(0.034)\end{array}$ & & \\
\hline $\mathrm{E}[\text { Board's average pollution ratio }]_{j, t-1}$ & & & $\begin{array}{c}0.541^{* * *} \\
(0.049)\end{array}$ & $\begin{array}{c}0.626^{* * *} \\
(0.045)\end{array}$ \\
\hline $\begin{array}{l}\mathrm{E}[\text { The range of the board's relative pollution } \\
\text { degree centrality }]_{j, t-1}\end{array}$ & & & $\begin{array}{l}-0.045 \\
(0.036)\end{array}$ & $\begin{array}{l}-0.036 \\
(0.035)\end{array}$ \\
\hline Firm's influence $_{j, t-1}$ & $\begin{array}{c}0.0003 \\
(0.0004)\end{array}$ & $\begin{array}{c}0.0003 \\
(0.0004)\end{array}$ & $\begin{array}{c}0.0003 \\
(0.0004)\end{array}$ & $\begin{array}{c}0.0003 \\
(0.0004)\end{array}$ \\
\hline
\end{tabular}

Robust standard errors clustered by firms are in parentheses. ${ }^{* * *} \mathrm{p}<0.01,{ }^{* *} \mathrm{p}<0.05,{ }^{*} \mathrm{p}<0.1$ 
Appendix A 
Table A.1: TRI facility level summary statistics

This table reports summary statistics at the facility level for the TRI dataset. The data are obtained from the US EPA's TRI program between 2000 and 2017. This paper includes all mandatory TRI reporting facilities in the US. Not all facilities in the TRI dataset are necessarily releasing toxic chemicals.

\begin{tabular}{lc}
\hline Variable & Mean or count \\
\hline Number of unique firms & 19,915 \\
Number of unique facilities & 42,212 \\
Average number of plants per firm & 2.242 \\
& $(7.575)$ \\
Average toxicity per facility (in thousands of pounds) & 124.680 \\
& $(4,200.330)$ \\
Average polluting ratio by firm & 0.434 \\
& $(0.301)$ \\
Average polluting ratio by facility & 0.532 \\
& $(0.499)$ \\
\hline
\end{tabular}

Standard deviations are in parentheses. 
Table A.2: TRI data summary statistics

This table summarizes the TRI data for each year from 2000 to 2017. The data are obtained from the US EPA's TRI program. This study includes all mandatory TRI reporting facilities in the US. Not all facilities in the TRI dataset are necessarily releasing toxic chemicals.

\begin{tabular}{lccc}
\hline Year & \multicolumn{2}{c}{ Unique number of } & $\begin{array}{c}\text { Toxicity } \\
\text { per facility }\end{array}$ \\
\cline { 2 - 3 } & Facilities & Firms & per \\
\hline 2000 & 36,486 & 16,987 & 186.224 \\
2001 & 36,209 & 16,739 & 158.446 \\
2002 & 35,653 & 16,240 & 137.118 \\
2003 & 35,405 & 15,969 & 129.340 \\
2004 & 35,131 & 15,793 & 123.292 \\
2005 & 35,019 & 15,591 & 127.551 \\
2006 & 34,848 & 15,441 & 127.876 \\
2007 & 34,647 & 15,286 & 122.698 \\
2008 & 34,394 & 15,108 & 115.639 \\
2009 & 33,853 & 14,905 & 101.518 \\
2010 & 33,939 & 14,994 & 113.424 \\
2011 & 33,808 & 14,952 & 122.743 \\
2012 & 33,916 & 14,934 & 108.545 \\
2013 & 33,908 & 14,944 & 123.510 \\
2014 & 33,926 & 14,979 & 117.881 \\
2015 & 33,958 & 14,953 & 102.088 \\
2016 & 34,067 & 15,079 & 103.128 \\
2017 & 34,394 & 15,194 & 115.684 \\
\hline
\end{tabular}

${ }^{a}$ In thousands of pounds. 
Table A.3: TRI industry sector data summary statistics

This table reports summary statistics about toxic releases for different industrial sectors in the TRI dataset. The data are obtained from the US EPA's TRI program between 2000 and 2017. This study includes all mandatory TRI reporting facilities in the US. We use the industrial sectors defined by the TRI program.

\begin{tabular}{lrrr}
\hline Industry Sector & \multicolumn{2}{c}{ Unique number of } & $\begin{array}{c}\text { Toxicity } \\
\text { per facility }\end{array}$ \\
\cline { 2 - 3 } & Facilities & Firms & $2,231.71$ \\
Apparel & 16 & 21 & $46,502.84$ \\
Beverages & 76 & 164 & $1,858.80$ \\
Chemical Wholesalers & 259 & 812 & $98,599.44$ \\
Chemicals & 3,002 & 5,925 & $86,867.46$ \\
Coal Mining & 95 & 179 & $4,362.11$ \\
Computers and Electronic Products & 1,360 & 2,191 & $898,985.10$ \\
Electric Utilities & 329 & 888 & $1,008,96.116 .14$ \\
Electrical Equipment & 519 & 1,149 & $18,232.35$ \\
Fabricated Metals & 3,326 & 5,515 & $54,218.04$ \\
Food & 885 & 2,741 & $17,865.09$ \\
Furniture & 384 & 646 & $662,878.39$ \\
Hazardous Waste & 88 & 360 & $18,458.95$ \\
Leather & 73 & 90 & $5,422.72$ \\
Machinery & 1,028 & 2,119 & 128 \\
Metal Mining & 66 & 128 & $13,383,882.00$ \\
Miscellaneous Manufacturing & 533 & 836 & $15,244.63$ \\
Nonmetallic Mineral Product & 871 & 3,840 & $15,163.07$ \\
Other & 376 & 1,237 & $58,112.79$ \\
Paper & 345 & 755 & $396,704.74$ \\
Petroleum & 376 & 1,161 & $137,381.63$ \\
Petroleum Bulk Terminals & 318 & 1,024 & $3,436.34$ \\
Plastics and Rubber & 1,598 & 2,627 & $29,018.49$ \\
Primary Metals & 1,472 & 2,612 & $355,596.27$ \\
Printing & 210 & 378 & $42,681.02$ \\
Publishing & 15 & 18 & 373.39 \\
Textile Product & 58 & 112 & $3,332.00$ \\
Textiles & 209 & 324 & $11,068.16$ \\
Tobacco & 19 & 53 & $92,041.75$ \\
Transportation Equipment & 1,271 & 2,647 & $31,907.57$ \\
Wood Products & 610 & 1,352 & $17,537.35$ \\
\hline a In thousands of pounds & & & \\
& & &
\end{tabular}


Table A.4: BoardEx firm level summary statistics

This table reports summary statistics for the BoardEx dataset. BoardEx is a global data management firm specializing in relationship mapping and intelligence. This study uses the BoardEx dataset for North America. A polluting firm is defined as a firm with at least one facility releasing toxic material above the EPA's threshold in a given year.

\begin{tabular}{lc}
\hline Variable & Mean or count \\
\hline Number of unique firms & 157,997 \\
Number of unique directors & 119,607 \\
Average number of directors per firm & 2.518 \\
& $(3.012)$ \\
Director's' average existing period in BoardEx & 10.624 \\
Average term of a director in a firm & $(5.684)$ \\
& 5.560 \\
Director's probability of being a board member in a polluting firm & $(4.668)$ \\
& 0.049 \\
\hline
\end{tabular}

Standard deviations are in parentheses. 
Table A.5: BoardEx data summary statistics

This table reports summary statistics for the BoardEx data from 2000 to 2017. BoardEx is a global data management firm specializing in relationship mapping and intelligence. This study only uses the BoardEx dataset for North America.

\begin{tabular}{lcc}
\hline Year & Number of unique firms & Number of unique directors \\
\hline 2000 & 46,239 & 52,367 \\
2001 & 47,375 & 55,567 \\
2002 & 47,894 & 57,855 \\
2003 & 48,939 & 60,594 \\
2004 & 50,881 & 63,765 \\
2005 & 53,005 & 66,266 \\
2006 & 54,905 & 68,805 \\
2007 & 57,184 & 70,961 \\
2008 & 58,180 & 72,171 \\
2009 & 59,135 & 72,740 \\
2010 & 60,921 & 73,799 \\
2011 & 61,992 & 74,990 \\
2012 & 63,259 & 76,454 \\
2013 & 64,395 & 78,193 \\
2014 & 65,146 & 79,719 \\
2015 & 65,356 & 80,759 \\
2016 & 64,503 & 80,969 \\
2017 & 88,851 & 84,686 \\
\hline
\end{tabular}


Table A.6: U. S. Census tract level summary statistics

This table reports summary statistics for the US Census data set provided by the United States Census Bureau. We also obtain population density information created by the Agency for Toxic Substances and Disease Registry. Given that our data spans two census periods, we use 2010 locations as fixed geographic locations. As in De Silva et al. (2016, 2021), we linearly impute and estimate the missing data to estimate the population density, minority ratio, the proportion of individuals with a college degree, and median household income from 2000 to 2008.

\begin{tabular}{lc}
\hline Variable & Mean or count \\
\hline Number of unique tracts (based on 2010 Census data) & 73,082 \\
Total population & $4,133.523$ \\
& $(1,878.227)$ \\
Population density (per square mile) & $5,165.112$ \\
& $(11,482.190)$ \\
Number of households & $1,039.065$ \\
Median household income & $(507.029)$ \\
& $64,271.900$ \\
College ratio & $(29,285.710)$ \\
& 0.256 \\
Minority ratio & $(0.215)$ \\
Number of special tracts & 0.244 \\
Tract is located in a Mexico border County & $(0.249)$ \\
Tract is located in a Canada border County & 961 \\
Tract is located in an MSA County & 1,521 \\
Tract is located in an urban County & 2,933 \\
Tract is located in a rural County & 60,909 \\
Tract is located in a costal County & 10,569
\end{tabular}

Standard deviations are in parentheses. 
Table A.7: Censored linear regression results for total release

This table reports censored linear regression results for total releases. We have left-censored the data for toxic releases per firm per year and estimated our empirical models using censored regression techniques. Columns 1 and 4 are the reference points that report linear regression results with industry effects. Columns 2 and 5 report results from censored regression similar to the ones estimated via linear regression. Columns 3 and 6 report censored regression results with facility-level random effects controlling for facility-level unobservable heterogeneity. We report the results for all facilities in Panel A and for BoardEx firms in Panel B. All regressions include log number of plants per firm, log of median household income, minority ratio, college ratio, and $\log$ of population density in addition to indicators for facilities siting in a special tract, MSA, Urban, and Costal Counties, located in a county that border Mexico or Canada, industry effects, and time effects.

\begin{tabular}{|c|c|c|c|c|c|c|}
\hline \multirow[t]{4}{*}{ Variable } & \multicolumn{6}{|c|}{ Log of toxicity released $j t$} \\
\hline & \multicolumn{6}{|c|}{ All facilities } \\
\hline & \multirow{2}{*}{$\begin{array}{c}\text { OLS } \\
(1)\end{array}$} & \multicolumn{2}{|c|}{ Censored } & \multirow{2}{*}{$\begin{array}{c}\text { OLS } \\
(4)\end{array}$} & \multicolumn{2}{|c|}{ Censored } \\
\hline & & $(2)$ & $(3)$ & & $(5)$ & $(6)$ \\
\hline \multicolumn{7}{|l|}{ Panel A: All facilities } \\
\hline Board's average pollution ratio $j, t-1$ & $\begin{array}{c}3.604^{* * *} \\
(0.211)\end{array}$ & $\begin{array}{c}3.875^{* * *} \\
(0.033)\end{array}$ & $\begin{array}{c}3.128^{* * * *} \\
(0.049)\end{array}$ & & & \\
\hline $\begin{array}{l}\text { The range of the board's relative pollution } \\
\text { degree centrality } j, t-1\end{array}$ & $\begin{array}{c}-1.365^{* * *} \\
(0.228)\end{array}$ & $\begin{array}{c}-1.598^{* * *} \\
(0.028)\end{array}$ & $\begin{array}{c}-0.403^{* * *} \\
(0.048)\end{array}$ & & & \\
\hline $\mathrm{E}[\text { Board's average pollution ratio }]_{j, t-1}$ & & & & $\begin{array}{c}7.084^{* * *} \\
(0.414)\end{array}$ & $\begin{array}{c}7.614^{* * *} \\
(0.064)\end{array}$ & $\begin{array}{c}6.148^{* * *} \\
(0.096)\end{array}$ \\
\hline $\begin{array}{l}\mathrm{E}[\text { The range of the board's relative pollution } \\
\text { degree centrality }]_{j, t-1}\end{array}$ & & & & $\begin{array}{c}-2.688^{* * *} \\
(0.450)\end{array}$ & $\begin{array}{c}-3.143^{* * *} \\
(0.055)\end{array}$ & $\begin{array}{c}-0.779^{* * *} \\
(0.095)\end{array}$ \\
\hline Firm's influence $_{j, t-1}$ & $\begin{array}{l}-22.758 \\
(23.492)\end{array}$ & $\begin{array}{l}-12.857 \\
(12.105)\end{array}$ & $\begin{array}{c}28.525 \\
(21.297)\end{array}$ & $\begin{array}{l}-22.770 \\
(23.482)\end{array}$ & $\begin{array}{l}-12.881 \\
(12.105)\end{array}$ & $\begin{array}{c}28.412 \\
(21.297)\end{array}$ \\
\hline Log of total industrial toxicity $i, t$ & $\begin{array}{c}0.241^{* * *} \\
(0.030)\end{array}$ & $\begin{array}{c}1.059^{* * *} \\
(0.033)\end{array}$ & $\begin{array}{c}2.442^{* * *} \\
(0.029)\end{array}$ & $\begin{array}{c}0.241^{* * *} \\
(0.030)\end{array}$ & $\begin{array}{c}1.059^{* * *} \\
(0.033)\end{array}$ & $\begin{array}{c}2.441^{* * *} \\
(0.029)\end{array}$ \\
\hline Facility belongs to a BoardEx firm $i, t$ & $\begin{array}{c}-0.659^{* * *} \\
(0.151)\end{array}$ & $\begin{array}{c}-0.869^{* * *} \\
(0.019)\end{array}$ & $\begin{array}{c}-0.807^{* * *} \\
(0.094)\end{array}$ & $\begin{array}{c}-0.659^{* * *} \\
(0.151)\end{array}$ & $\begin{array}{c}-0.869^{* * *} \\
(0.019)\end{array}$ & $\begin{array}{c}-0.808^{* * *} \\
(0.094)\end{array}$ \\
\hline Facility belongs to a listed firm $_{i, t}$ & $\begin{array}{l}-0.143 \\
(0.149)\end{array}$ & $\begin{array}{c}-0.210^{* * *} \\
(0.021)\end{array}$ & $\begin{array}{c}-0.388^{* * *} \\
(0.054)\end{array}$ & $\begin{array}{l}-0.141 \\
(0.149)\end{array}$ & $\begin{array}{c}-0.208^{* * *} \\
(0.021)\end{array}$ & $\begin{array}{c}-0.389^{* * *} \\
(0.054)\end{array}$ \\
\hline Facility level random effects & & & Yes & & & Yes \\
\hline Observations & 582,722 & 582,722 & & 582,722 & 582,722 & \\
\hline $\mathrm{R}^{2}$ & 0.128 & & & 0.128 & & \\
\hline Log likelihood & & $-1.252 \mathrm{e}+06$ & $-994,300$ & & $-1.252 \mathrm{e}+06$ & $-994,295$ \\
\hline Uncensored observations & & 310,227 & 310,227 & & 310,227 & 310,227 \\
\hline \multicolumn{7}{|l|}{ Panel B: BoardEx facilities } \\
\hline Board's average pollution ratio $j, t-1$ & $\begin{array}{c}3.540 * * * \\
(0.205)\end{array}$ & $\begin{array}{c}3.834^{* * *} \\
(0.033)\end{array}$ & $\begin{array}{c}3.150^{* * *} \\
(0.048)\end{array}$ & & & \\
\hline $\begin{array}{l}\text { The range of the board's relative pollution } \\
\text { degree centrality } j, t-1\end{array}$ & $\begin{array}{c}-1.146^{* * *} \\
(0.223)\end{array}$ & $\begin{array}{c}-1.358^{* * *} \\
(0.029)\end{array}$ & $\begin{array}{c}-0.293^{* * *} \\
(0.047)\end{array}$ & & & \\
\hline $\mathrm{E}[\text { Board's average pollution ratio }]_{j, t-1}$ & & & & $\begin{array}{c}6.957^{* * *} \\
(0.402)\end{array}$ & $\begin{array}{c}7.535^{* * *} \\
(0.066)\end{array}$ & $\begin{array}{c}6.191^{* * *} \\
(0.093)\end{array}$ \\
\hline $\begin{array}{l}\mathrm{E} \text { [The range of the board's relative pollution } \\
\text { degree centrality }]_{j, t-1}\end{array}$ & & & & $\begin{array}{c}-2.254^{* * *} \\
(0.440)\end{array}$ & $\begin{array}{c}-2.670^{* * *} \\
(0.057)\end{array}$ & $\begin{array}{c}-0.562^{* * *} \\
(0.093)\end{array}$ \\
\hline Firm's influence $_{j, t-1}$ & $\begin{array}{l}-30.907 \\
(22.519)\end{array}$ & $\begin{array}{l}-21.736^{*} \\
(12.205)\end{array}$ & $\begin{array}{c}28.036 \\
(20.641)\end{array}$ & $\begin{array}{l}-30.924 \\
(22.507)\end{array}$ & $\begin{array}{l}-21.766^{*} \\
(12.205)\end{array}$ & $\begin{array}{c}27.915 \\
(20.640)\end{array}$ \\
\hline Log of total industrial toxicity $i, t$ & $\begin{array}{c}0.264^{* * *} \\
(0.033)\end{array}$ & $\begin{array}{c}1.071^{* * *} \\
(0.045)\end{array}$ & $\begin{array}{c}2.304^{* * *} \\
(0.040)\end{array}$ & $\begin{array}{c}0.264^{* * *} \\
(0.033)\end{array}$ & $\begin{array}{c}1.070^{* * *} \\
(0.045)\end{array}$ & $\begin{array}{c}2.303^{* * *} \\
(0.040)\end{array}$ \\
\hline Facility belongs to a listed firm $_{i, t}$ & $\begin{array}{l}-0.114 \\
(0.140)\end{array}$ & $\begin{array}{c}-0.172^{* * *} \\
(0.021)\end{array}$ & $\begin{array}{c}-0.404^{* * *} \\
(0.054)\end{array}$ & $\begin{array}{l}-0.112 \\
(0.140)\end{array}$ & $\begin{array}{c}-0.171^{* * *} \\
(0.021)\end{array}$ & $\begin{array}{c}-0.405^{* * *} \\
(0.054)\end{array}$ \\
\hline Facility level random effects & & & Yes & & & Yes \\
\hline Observations & 288,277 & 288,277 & 288,277 & 288,277 & 288,277 & 288,277 \\
\hline $\mathrm{R}^{2}$ & 0.168 & & & 0.168 & & \\
\hline Log likelihood & & $-616,971$ & $-478,887$ & & $-616,963$ & $-590,056$ \\
\hline Uncensored observations & 152,861 & 152,861 & 152,861 & 152,861 & 152,861 & 152,861 \\
\hline
\end{tabular}

